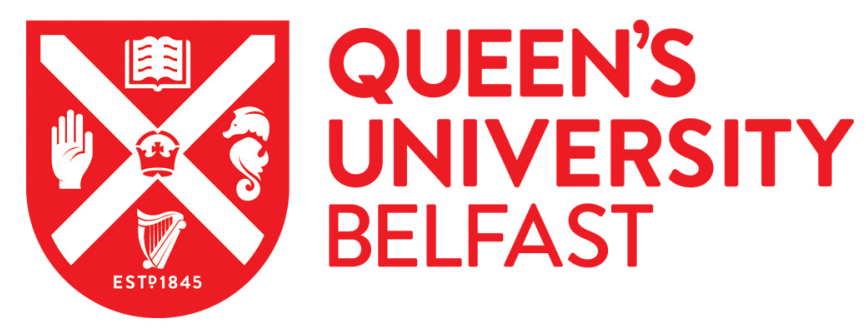

\title{
Transparent, UV-proof and mechanically strong montmorillonite/alginate/Ca2+ nanocomposite hydrogel films with solvent sensitivity
}

Su, X., \& Chen, B. (2018). Transparent, UV-proof and mechanically strong montmorillonite/alginate/Ca2+ nanocomposite hydrogel films with solvent sensitivity. Applied Clay Science, 165, 223-233.

https://doi.org/10.1016/j.clay.2018.07.044

Published in:

Applied Clay Science

Document Version:

Peer reviewed version

Queen's University Belfast - Research Portal:

Link to publication record in Queen's University Belfast Research Portal

Publisher rights

(c) 2018 Elsevier B.V. All rights reserved.

This manuscript version is made available under the CC-BY-NC-ND 4.0 license http://creativecommons.org/licenses/by-nc-nd/4.0/,which permits distribution and reproduction for noncommercial purposes, provided the author and source are cited.

\section{General rights}

Copyright for the publications made accessible via the Queen's University Belfast Research Portal is retained by the author(s) and / or other copyright owners and it is a condition of accessing these publications that users recognise and abide by the legal requirements associated with these rights.

\section{Take down policy}

The Research Portal is Queen's institutional repository that provides access to Queen's research output. Every effort has been made to ensure that content in the Research Portal does not infringe any person's rights, or applicable UK laws. If you discover content in the Research Portal that you believe breaches copyright or violates any law, please contact openaccess@qub.ac.uk. 


\title{
Transparent, UV-proof and mechanically strong montmorillonite/alginate/Ca ${ }^{2+}$ nanocomposite hydrogel films with solvent sensitivity
}

\author{
Xing $\mathrm{Su}^{\mathrm{a}}$, Biqiong $\mathrm{Chen}^{\mathrm{b} *}$ \\ a Department of Materials Science and Engineering, University of Sheffield, Mappin Street, \\ Sheffield S1 3JD, United Kingdom. \\ ${ }^{\mathrm{b}}$ School of Mechanical and Aerospace Engineering, Queen's University Belfast, Stranmillis \\ Road, Belfast BT9 5AH, United Kingdom.
}

*Corresponding author. E-mail address: b.chen@qub.ac.uk. Telephone: +44 (0)28 90974116

\begin{abstract}
Fully swollen montmorillonite/alginate/ $\mathrm{Ca}^{2+}\left(\mathrm{Ca}^{2+}-\mathrm{MtAlg}\right)$ nanocomposites with a specific chemical composition are expected to show well-ordered microstructure, excellent mechanical properties, unique optical properties and solvent sensitivities. Inspired by nacre, $\mathrm{Ca}^{2+}$-MtAlg nanocomposite hydrogel films with high montmorillonite mass contents $(\geq 20 \%)$ were synthesised by solution casting, followed by subsequent ionic crosslinking. The fully swollen $\mathrm{Ca}^{2+}$-MtAlg nanocomposite films were mechanically flexible and stable in water. By regulating the relative content of alginate and $\mathrm{Mt}$, it was possible for the hydrogel films to reach a high tensile strength of $28 \mathrm{MPa}$. $\mathrm{Ca}^{2+}$-MtAlg hydrogel films also showed acceptable transparency and high efficiency in blocking ultraviolet light. Furthermore, they demonstrated solvent sensitivity; the hydrogels lost water in either methanol or acetone, the one with an Mt/Alg mass ratio of 1:4 coiled seriously in acetone while those with a lower mass ratio were more stable in either methanol or acetone. Overall, $\mathrm{Ca}^{2+}{ }_{-} \mathrm{MtAlg}$ nanocomposite hydrogel films have the potential for use in stimuli-responsive load-bearing biomedical applications, skin care and beyond.
\end{abstract}

Keywords: clay mineral/polymer nanocomposite hydrogel; montmorillonite; fully swollen state; mechanical properties; UV-proof; solvent-sensitivity. 


\section{Introduction}

Clay mineral/polymer nanocomposites (CPNs) have been developed for years since the montmorillonite (Mt)/nylon 6 nanocomposites were first synthesised by Toyota Research Centre (Usuki et al., 1993). Single layers of Clay minerals such as Mt are known to have large aspect ratios and superior mechanical properties (Chen and Evans, 2006). CPNs have drawn considerable attention as by dispersing a small mass content of clay mineral (lower than $10 \mathrm{wt} . \%$ ) into the polymer matrix, the mechanical properties and barrier properties can be significantly improved in respect to those of the neat polymer (Giannelis, 1998; Okada and Usuki, 2007). However, the mass content of clay mineral in CPNs was usually limited to be under $10 \%$ because when a higher amount of clay mineral was incorporated, the dispersion could be worse and thus deteriorate the performance (Chen, 2004; Chen et al., 2008).

Nacre-mimetics paved a promising way for synthesising CPN with high amounts of clay mineral (Mayer, 2005). By the ordered alignment of the inorganic building blocks, ultrahigh Young's modulus and tensile strength could be achieved (Fratzl et al., 2007). There were many methods for mimicking nacre, such as layer-by-layer assembly (Tang et al., 2003), vacuum filtration (Yao et al., 2010) and solution casting induced self-assembly (Kochumalayil et al., 2012). Montmorillonite, as an interesting inorganic filler with a single layer thickness of $\sim 1 \mathrm{~nm}$ (Chen and Evans, 2004), has been utilised for making nacremimicking bionanocomposite materials with polymers such as chitosan (Yao et al., 2010) by solvent evaporation induced self-assembly method. The resultant materials displayed a unique ordered microstructure and excellent mechanical properties. The obtained Mt/chitosan nanocomposite films, with a high Mt mass content of 76\%, a Young's modulus of $10.7 \mathrm{GPa}$, a tensile strength of $76 \mathrm{MPa}$ and a low strain at break of $0.97 \%$ were achieved.

Alginates (Algs), a kind of polysaccharides which are abundant in brown algae, are made of (1-4)-linked $\beta$-d-mannuronic acid units and $\alpha$-l-guluronic acid units (Norajit et al., 2010). 
$\mathrm{G}$ blocks of the adjacent alginate polymer chains can be efficiently crosslinked through the ionic bonding by multivalent cations such as $\mathrm{Ca}^{2+}$ (George and Abraham, 2006). They are widely used in the areas of food packaging (Abdollahi et al., 2013), drug delivery (Tonnesen and Karlsen, 2002) and enzyme carrying (Gorenek et al., 2004) because of the excellent biocompatibility (Kim et al., 2011) and biodegradability (Schaumann and Weide, 1990). However, poor mechanical and gas barrier properties, as well as low stability in water, limit their application in the aquatic environment (Rhim, 2004). In order to overcome these drawbacks, Mt/Alg nanocomposites were developed. It was reported previously that based on the Velcro effect, the tetrahedral $\mathrm{SiO}_{4}$ geometry and $\mathrm{OH}$ groups of Mt layers are likely to form dense hydrogen bonding networks with many hydrophilic polymers such as poly(vinyl alcohol), chitosan and Alg (Podsiadlo et al., 2007). In particular, Alg is known to be able to form dense hydrogen bonds with Mt layers because it is rich in oxygen containing functional groups such as $-\mathrm{OH},-\mathrm{COO}$, and -O- (Bhattarai et al., 2006). Mt/Alg nanocomposite dry films with an Mt mass content below 5\% were reported recently (Abdollahi et al., 2013; Alboofetileh et al., 2013; Tezcan et al., 2012). By incorporating a low mass content of Mt (< $5 \%$ ), the water solubility of Mt/Alg nanocomposite films could be reduced by $40 \%$, illustrating much better stability in water than that of the conventional Alg dry films (Abdollahi et al., 2013; Alboofetileh et al., 2013). With the incorporation of $3 \mathrm{wt} \% \mathrm{Mt}$ in respect to $\mathrm{Alg}$, tensile strength of the nanocomposite dry film could reach $28 \mathrm{MPa}$, which was 55\% higher than that of the neat Alg dry film (Alboofetileh et al., 2013). As for the optical properties, the incorporation of Mt did not significantly reduce the transparency of Alg film, and the resultant nanocomposite films could effectively inhibit the transmittance of UV light (Abdollahi et al., 2013; Alboofetileh et al., 2013; Tezcan et al., 2012). Mt/Alg nanocomposites with high clay mineral mass contents $(\geq 50 \%)$ were also investigated (Zlopasa et al., 2015). By the solution evaporation induced self-assembly method, highly 
ordered microstructure was obtained in the dry films. It was believed that while both Alg chains and Mt surface are negatively charged, the unique nacre-mimicking structure could be achieved by the electrostatic interaction between negatively charged Alg chains and positively charged Mt edge which restricted the movement of Mt layers during solution casting (Zlopasa et al., 2015). However, the mechanical properties of these Mt/Alg nanocomposite films fully soaked in water were not studied so their stability in water is unknown.

Due to the high solubility of Alg in water, full or partial dissolution of $\mathrm{Mt} / \mathrm{Alg}$ films in water is inevitable. However, Alg becomes insoluble in water when G-blocks of Alg chains are ionically crosslinked by $\mathrm{Ca}^{2+}$ (George and Abraham, 2006). Insoluble $\mathrm{Ca}^{2+}{ }_{-} \mathrm{MtAlg}$ nanocomposite films were synthesised by immersing the solution cast $\mathrm{Mt} / \mathrm{Alg}$ films in $\mathrm{CaCl}_{2}$ solution (Vale et al., 2005). In this case, a low Mt mass content of 3\% was applied, and the barrier property against benzaldehyde was found to be significantly improved. Recently, nacre-like $\mathrm{Ca}^{2+}$-MtAlg nanocomposite films with high Mt mass contents (up to 70\%) from the work of Liang et al. (2016) (L-Ca $\left.{ }^{2+}-\mathrm{MtAlg}\right)$ were synthesised from the $\mathrm{Ca}^{2+}$ pre-crosslinked $\mathrm{Mt} / \mathrm{Alg}$ turbidity by vacuum-assisted filtration method. The dry $\mathrm{L}-\mathrm{Ca}^{2+}-\mathrm{MtAlg}$ films could achieve a high tensile strength of $280 \mathrm{MPa}$ and a high toughness of $7.2 \mathrm{MJ} \mathrm{m} \mathrm{m}^{-3}$, over 1.5 times of those of $\mathrm{Mt} / \mathrm{Alg}$ nanocomposite films without $\mathrm{Ca}^{2+}$ crosslinking. Besides, dry L$\mathrm{Ca}^{2+}$-MtAlg films also showed a remarkable tensile strength of $170 \mathrm{MPa}$ at $100{ }^{\circ} \mathrm{C}$. Excellent fire-retardant properties and strong shape response to alcohols were also achieved. However, the mechanical properties of these $\mathrm{Mt} / \mathrm{Alg} / \mathrm{Ca}^{2+}$ nanocomposite films fully swollen in water were not reported.

Inspired by the previous studies, this work aimed to synthesise $\mathrm{Ca}^{2+}-\mathrm{MtAlg}$ nanocomposite films with high Mt mass contents ( $\geq 20 \%$ based on the dry nanocomposites) by solution casting followed by ionic crosslinking. Unlike the previous results which focused on the 
mechanical properties of the dry Mt/Alg nanocomposites, it was hypothesised in this study that the $\mathrm{Ca}^{2+}$-MtAlg nanocomposite films, with a high mass content of $\mathrm{Mt}(\geq 20 \%)$ and the in situ $\mathrm{Ca}^{2+}$-crosslinked Alg network, would be capable of showing well-ordered microstructure and excellent mechanical properties under the fully swollen state in the aquatic environment, because of $\mathrm{Ca}^{2+}$-Alg ionic crosslinking, Mt-Alg hydrogen bonding, Mt edge-Alg electrostatic interaction and $\mathrm{Ca}^{2+}-\mathrm{Mt}$ surface electrostatic interaction. With varying $\mathrm{Mt} / \mathrm{Alg}$ ratios, the fully swollen $\mathrm{Ca}^{2+}$-MtAlg nanocomposite films could display distinct optical properties and solvent sensitivity due to their different microstructures. These nanocomposite films might serve in stimuli-responsive load-bearing biomedical applications, skin care and beyond.

\section{Materials and methods}

\subsection{Materials}

Sodium alginate (Alg), with a purity of $99 \%$, viscosity $\left(1 \%\right.$ in water, viscosity at $25{ }^{\circ} \mathrm{C} \geq$ $0.015 \mathrm{~Pa} \mathrm{~s}$ ), molar mass (12000 40000, determined by gel permeation chromatography), mannuronic/guluronic ratio (1.6, determined by proton nuclear magnetic resonance), and calcium chloride anhydrous $\left(\mathrm{CaCl}_{2}\right)$ with a purity $\geq 96.0 \%$ were purchased from Sigma Aldrich. Sodium montmorillonite (product name: BH Natural, denoted as Mt, chemical formula: $\left.3.36 \mathrm{H}_{2} \mathrm{O} \cdot \mathrm{Na}_{0.41} \mathrm{Al}_{3.53} \mathrm{Mg}_{0.46} \mathrm{Si}_{8} \mathrm{O}_{20}(\mathrm{OH})_{4}\right)$ with a cation exchange capability of 90 meq $(100 \mathrm{~g})^{-1}$ was supplied by Blackhill Bentonite LLC (Wyoming). Methanol (assay $\geq$ 99.8\%) and acetone (assay $\geq 99 \%$ ) were provided by Fisher Scientific.

\subsection{Preparation of $\mathrm{Ca}^{2+}$-MtAlg nanocomposite films}

$15 \mathrm{~g}$ Mt was dispersed in $1 \mathrm{~L}$ distilled water for $24 \mathrm{~h}$ on a table roller. It was followed by 30 min' sonication by and another 24 h' standing settling. Then the unexfoliated clay mineral precipitate was separated, dried and weighed so that the exfoliated Mt layers in the 
supernatant were collected and their concentration of Mt was calculated to be $0.012 \mathrm{~g} \mathrm{~mL}^{-1}$ (Su et al., 2017).

The process of synthesizing Alg and its nanocomposite films was described below. Typically, a predetermined amount of Alg $(0.8 \mathrm{~g})$ was dissolved in distilled water to prepare a solution with an Alg content of $0.010 \mathrm{~g} \mathrm{~mL}^{-1}$ by stirring for $3 \mathrm{~h}$ at ambient temperature. Then the predetermined amount of Mt dispersion $(16.7 \mathrm{~mL})$ containing $0.2 \mathrm{~g}$ Mt layers was added to the Alg solution drop by drop under stirring. The mixed Mt/Alg dispersion was diluted to a solid concentration of $0.010 \mathrm{~g} \mathrm{~mL}^{-1}$ which was further stirred for $24 \mathrm{~h}$ to achieve homogeneous dispersion. Afterward, the Mt/Alg dispersion was poured into polystyrene petri dishes and allowed to dry in an oven at $60{ }^{\circ} \mathrm{C}$ until the mass stayed constant. Finally, the as-prepared Mt/Alg nanocomposite film was peeled off from the petri dishes, denoted as Mt2Alg8 where 2 and 8 refer to ten times of the masses of Mt and Alg respectively. Following the same procedure, Mt3Alg7 $(\mathrm{Mt} / \mathrm{Alg}=0.3 \mathrm{~g} / 0.7 \mathrm{~g})$ and $\mathrm{Mt5Alg} 5(\mathrm{Mt} / \mathrm{Alg}=0.5$ $\mathrm{g} / 0.5 \mathrm{~g}$ ) were also prepared. Therefore, the mass ratios of Mt/Alg were varied to be $1: 4,3: 7$ and 1:1. The total mass of solid and the solid concentration of the mixture for solution casting were fixed at $1 \mathrm{~g}$ and $0.010 \mathrm{~g} \mathrm{~mL}^{-1}$. These $\mathrm{Mt} / \mathrm{Alg}$ nanocomposite films were readily soluble in water. Alg films were also prepared for comparison by the same method with the $0.010 \mathrm{~g}$ $\mathrm{mL}^{-1}$ Alg solution without using Mt dispersion, denoted as Alg10.

$\mathrm{Ca}^{2+}$-MtAlg nanocomposite films were prepared by submerging the as-prepared Mt2Alg8, Mt3Alg7 and Mt5Alg5 films in a $0.3 \mathrm{M} \mathrm{CaCl}_{2}$ solution for $24 \mathrm{~h}$ to reach the equilibrium swelling state (Vale et al., 2005; Yang et al., 2013). All the $\mathrm{Ca}^{2+}-\mathrm{MtAlg}$ films were then immersed in distilled water for another $24 \mathrm{~h}$ to remove excess $\mathrm{Ca}^{2+}$ (Vale et al., 2005). The obtained fully swollen $\mathrm{Ca}^{2+}-\mathrm{MtAlg}$ nanocomposite hydrogel films were denoted as $\mathrm{Ca}^{2+}$ Mt2Alg8, $\mathrm{Ca}^{2+}-\mathrm{Mt} 3 \mathrm{Alg} 7$ and $\mathrm{Ca}^{2+}-\mathrm{Mt5} \mathrm{Alg} 5$, respectively. For comparison, the as-prepared Alg10 films were submerged in $\mathrm{CaCl}_{2}$ solution and then immersed in distilled water to make 
$\mathrm{Ca}^{2+}$ crosslinked Alg hydrogel films, denoted as $\mathrm{Ca}^{2+}-\mathrm{Alg} \cdot \mathrm{Ca}^{2+}-\mathrm{MtAlg}$ and $\mathrm{Ca}^{2+}-\mathrm{Alg}$ films were either kept in distilled water or freeze-dried by the FreeZone Triad Cascade Benchtop Freeze Dry System from LABCONCO under vacuum at $-15{ }^{\circ} \mathrm{C}$ for $2 \mathrm{~d}$ for future tests. In order to compare with $\mathrm{Ca}^{2+}-\mathrm{Mt} 3 \mathrm{Alg} 7$, some of $\mathrm{Ca}^{2+}-\mathrm{Mt} 3 \mathrm{Alg} 7$ and $\mathrm{Ca}^{2+}-\mathrm{Alg}$ films were dried and kept in an oven at $60{ }^{\circ} \mathrm{C}$, denoted as $\mathrm{D}-\mathrm{Ca}^{2+}-\mathrm{Mt} 3 \mathrm{Alg} 7$ and $\mathrm{D}-\mathrm{Ca}^{2+}-\mathrm{Alg}$, and so were Mt dispersion, Alg and Mt7Alg3 films for future tests.

In addition, some materials following the previously reported methods were made for comparison. $\mathrm{Ca}^{2+}-\mathrm{MtAlg}$ nanocomposite films with a Mt/Alg mass ratio of 3:97 were prepared by the same method of Vale et al (2005), denoted as $\mathrm{V}-\mathrm{Ca}^{2+}-\mathrm{Mt} 3 \mathrm{Alg} 97 . \mathrm{Ca}^{2+}-\mathrm{MtAlg}$ nanocomposite films with a Mt/Alg mass ratio of 3:7 were prepared following the method of Liang et al (2016), denoted as L-Ca ${ }^{2+}-\mathrm{Mt} 3 \mathrm{Alg} 7$. Mt/Alg/glycerol nanocomposite films with a Mt/Alg/glycerol mass ratio of 3:7:1.75 were synthesized following the method of Alboofetileh et al (2013), denoted as A-Mt3Alg7Gly1.75. These nanocomposite films were immersed in distilled water for $24 \mathrm{~h}$ to reach the equilibrium swelling state for future use.

\subsection{Characterisation}

X-ray diffraction (XRD) was carried out in the transmission mode by a STOE STADI P $(\mathrm{Cu} \mathrm{K} \alpha)$ diffractometer. The incident $\mathrm{X}$-ray wavelength, scan rate and step size were set to be $0.154 \mathrm{~nm}, 1.0^{\circ} \mathrm{min}^{-1}$ and $0.02^{\circ}$, respectively. Fourier transform infrared (FTIR) spectroscopy was carried out using a Spectrum 100 spectrophotometer (PerkinElmer) in the wavenumber region from 4000 to $600 \mathrm{~cm}^{-1}$ with a resolution of $1 \mathrm{~cm}^{-1}$. The samples were grinded into powders, put on a diamond ATR sensor and compressed. Before each test, a background scan was run first. Each sample was scanned for 8 times.

The tensile tests were conducted on a Hounsfield mechanical test equipment LTD according to ISO 527. The test samples were cut into dog-bone shape with a gauge length of $25 \mathrm{~mm}$ and a width of $3.5 \mathrm{~mm}$ by an ISO 2075 standard test sample cutter. The thickness of 
the test samples was measured by a digital caliper with a resolution of $0.01 \mathrm{~mm}$. A $10 \mathrm{~N}$ load cell was used, and the crosshead speed was set to be $5 \mathrm{~mm} \mathrm{~min}^{-1}$. At least 5 samples were tested for each material.

Swelling tests were done by submerging freeze-dried $\mathrm{Ca}^{2+}$-MtAlg films in distilled water until the mass stayed constant at room temperature. The equilibrium swelling ratio was defined as: $\varphi=\left(\mathrm{W}_{\mathrm{e}}-\mathrm{W}_{\mathrm{d}}\right) / \mathrm{W}_{\mathrm{d}} \times 100 \%$, where $\mathrm{W}_{\mathrm{e}}$ and $\mathrm{W}_{\mathrm{d}}$ represented the masses of the fully swollen sample and the dry sample before swelling tests, respectively, which were measured using an analytical balance. The fully swollen samples taken from water were gently wiped by tissue paper to remove the surface water and then immediately weighed. Five samples were tested for each material.

Ultraviolet-visible (UV-Vis) spectroscopy was conducted on a Perkin Elmer Lambda 900 spectrometer with a $1 \mathrm{~nm}$ resolution to measure the light transmittance of $\mathrm{Ca}^{2+}-\mathrm{MtAlg}$ and $\mathrm{Ca}^{2+}-\mathrm{Alg}$ films in the range of 250 800 nm.

Solvent-sensitivity tests were achieved by submerging flat $\mathrm{Ca}^{2+}-\mathrm{MtAlg}$ films in methanol or acetone for $24 \mathrm{~h}$. The shape-change of the films was observed in the solvent. Then the solvent-treated films were placed in distilled water to determine if they were able to recover their original shape.

$\mathrm{Ca}^{2+}-\mathrm{MtAlg}$ and $\mathrm{Ca}^{2+}-\mathrm{Alg}$ films were freeze-dried and fractured in liquid nitrogen for scanning electron microscopy (SEM). The topographic fracture surface of the samples with carbon coating was observed by an Inspect F FEG SEM operated at a voltage of $5 \mathrm{kV}$. The characteristic elements of $\mathrm{O}, \mathrm{Si}$ and $\mathrm{Ca}$ were detected by energy dispersive X-ray analysis (EDX).

The $\mathrm{Ca}^{2+}$ content in the nanocomposite films was estimated by thermogravimetric analysis (TGA) using a Pyris 1 TGA instrument (PerkinElmer). The dry samples were used 
for the analysis under the protection of $\mathrm{N}_{2}$ gas flow of $20 \mathrm{ml} \mathrm{min}^{-1}$. The heating range was from $25^{\circ} \mathrm{C} \sim 800{ }^{\circ} \mathrm{C}$ with a heating rate of $20^{\circ} \mathrm{C} \mathrm{min}^{-1}$.

\section{Results and discussion}

\subsection{Formation and structure of $\mathrm{Ca}^{2+}$-MtAlg nanocomposite films}

As seen in Scheme 1 (a), $\mathrm{Ca}^{2+}$-MtAlg films were synthesised following mainly four steps. First, the Mt dispersion and Alg solution were mixed and stirred to achieve a fine Mt-Alg adsorption and dispersion. Secondly, nacre-like MtAlg films were fabricated by solution casting, and Mt edge-Alg electrostatic interaction, Mt-Alg hydrogen bonding, together with the large specific surface area of Mt (Zlopasa et al., 2015), helped to form layered structure. Thirdly, MtAlg films were swollen in the $\mathrm{CaCl}_{2}$ solution and $\mathrm{Ca}^{2+}$ crosslinked $\mathrm{Alg}$ chains to form $\mathrm{Ca}^{2+}$-MtAlg. As a result, $\mathrm{G}$ blocks of $\mathrm{Alg}$ chains were crosslinked by divalent $\mathrm{Ca}^{2+}$ to form "egg-box" structure (George and Abraham, 2006; Liang et al., 2016). Some $\mathrm{Ca}^{2+}$ were also adsorbed onto the surface of Mt layers (Brevik and Burgess, 2012; Rytwo et al., 1996). At last, the excess $\mathrm{Ca}^{2+}$ were washed off by distilled water. The structure of $\mathrm{Ca}^{2+}-\mathrm{MtAlg}$ could be further depicted by XRD, FTIR, SEM and EDX as shown in Scheme 1 (b \& c), Figure 1 and Table 1. 

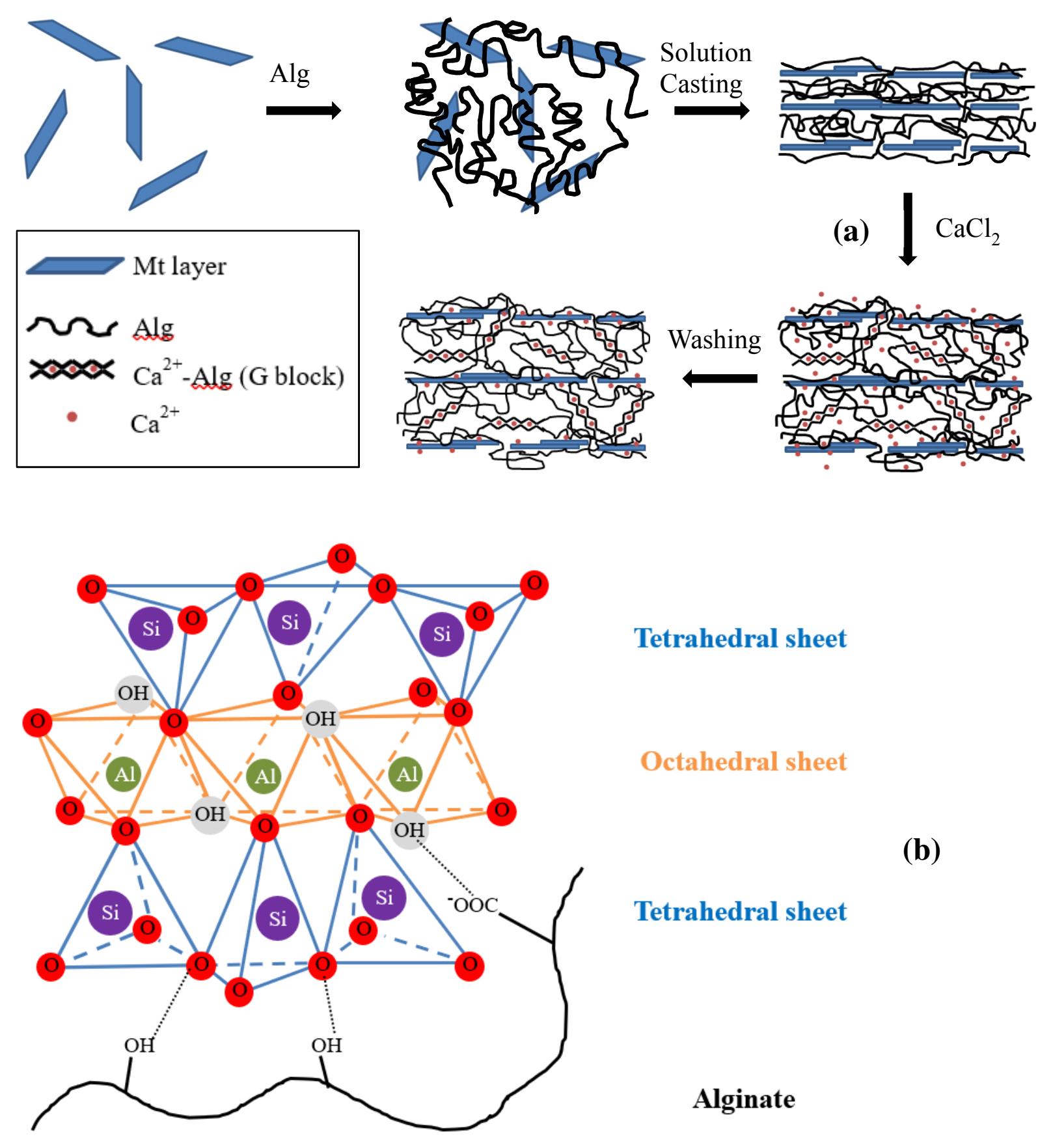

Tetrahedral sheet

\section{Octahedral sheet}

(b)

Tetrahedral sheet

\section{Alginate}

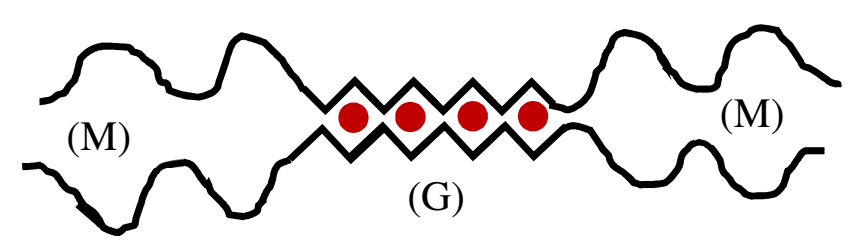

(c)

Scheme 1. (a) Schematic illustration of the synthesis of $\mathrm{Ca}^{2+}-\mathrm{MtAlg}$, (b) hydrogen bonding between $\mathrm{Mt}$ and $\mathrm{Alg}$, and (c) the chemical structure of crosslinked $\mathrm{Ca}^{2+}$-Alg blocks. 

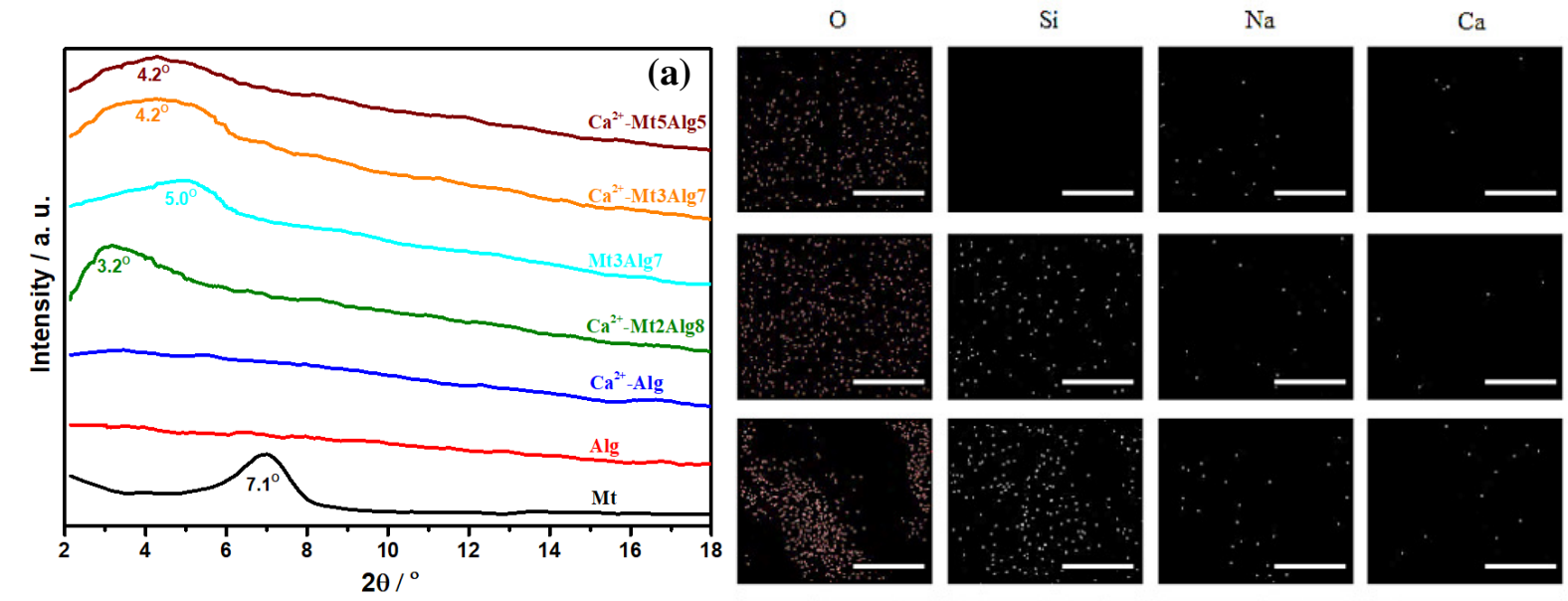

(c)
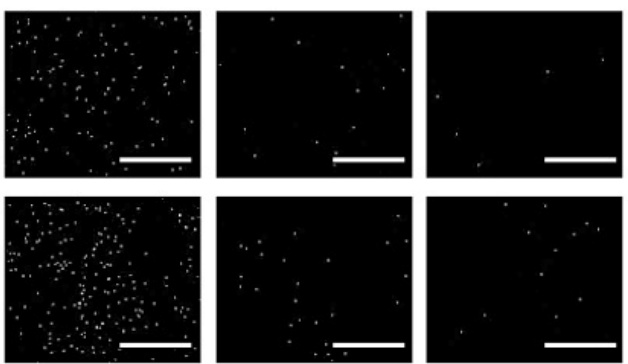

(d)
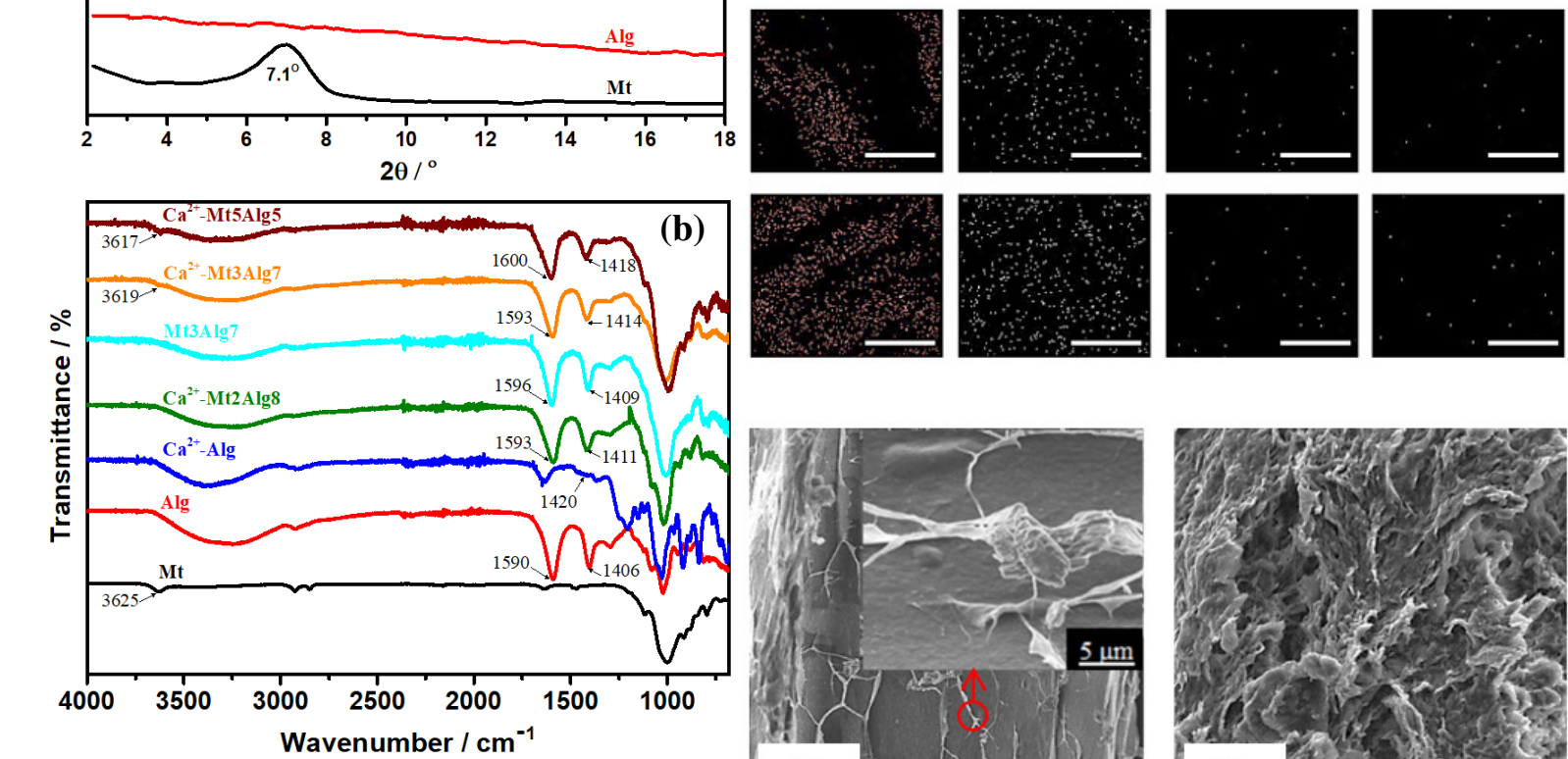

(e)
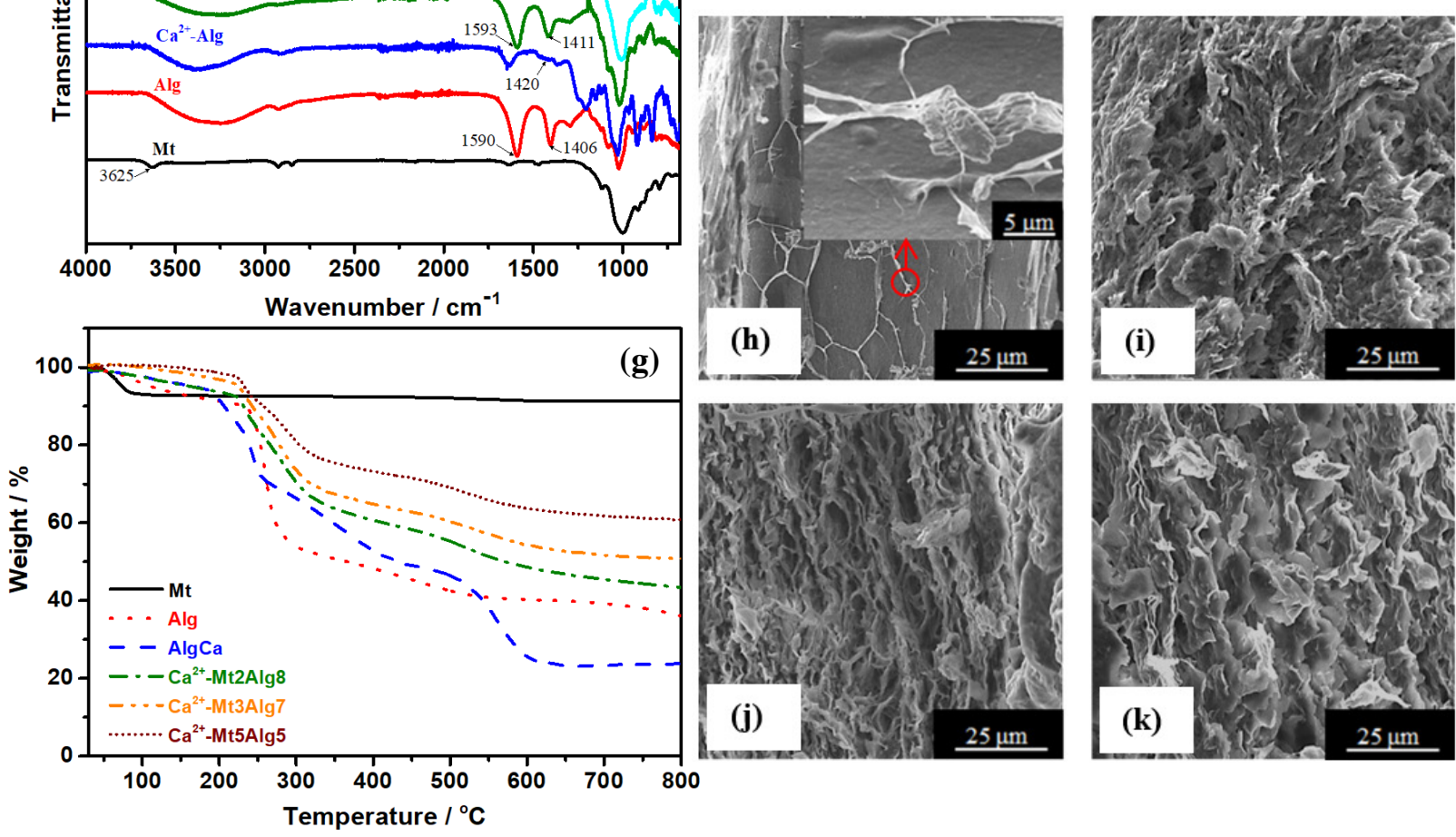

(f)
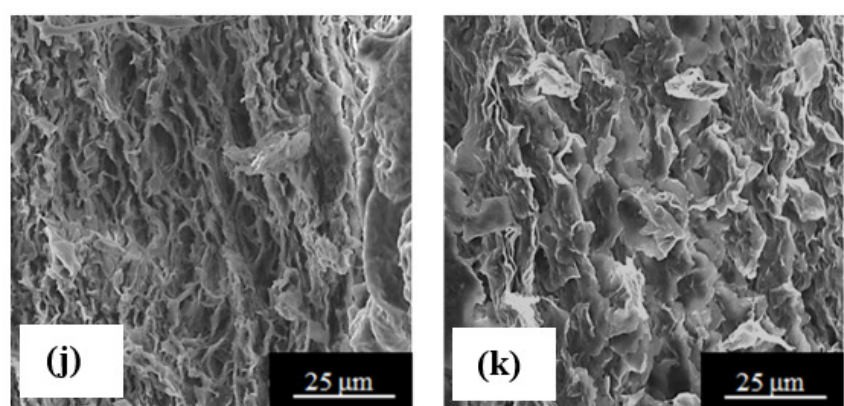

Fig. 1. (a) XRD traces of $\mathrm{Mt}$, $\mathrm{Alg}$ and their nanocomposites with and without $\mathrm{Ca}^{2+}$, as well as $\mathrm{Ca}^{2+}$-Alg; (b) FTIR spectra of $\mathrm{Mt}$, Alg and their nanocomposites with and without $\mathrm{Ca}^{2+}$; EDX graphs taken from the cross-sectional surface of (c) $\mathrm{Ca}^{2+}-\mathrm{Alg}$, (d) $\mathrm{Ca}^{2+}-\mathrm{Mt} 2 \mathrm{Alg} 8$, (e) $\mathrm{Ca}^{2+}-$ Mt3Alg7, and (f) $\mathrm{Ca}^{2+}-\mathrm{Mt5Alg} 5$ (scale bar: $10 \mu \mathrm{m}$ ); (g) TGA curves of Mt, Alg, $\mathrm{Ca}^{2+}-\mathrm{Alg}$ and Alg nanocomposites; and SEM images of the cross-sectional surface of freeze-dried (h) $\mathrm{Ca}^{2+}-\mathrm{Alg}$, (i) $\mathrm{Ca}^{2+}-\mathrm{Mt} 2 \mathrm{Alg} 8$, (j) $\mathrm{Ca}^{2+}-\mathrm{Mt} 3 \mathrm{Alg} 7$, and (k) $\mathrm{Ca}^{2+}-\mathrm{Mt} 5 \mathrm{Alg} 5$. 
Table 1. Diffraction angles, basal plane spacings, mass remain and estimated $\mathrm{Ca}^{2+}$ contents of $\mathrm{Mt}, \mathrm{Alg}$ and their nanocomposites with and without $\mathrm{Ca}^{2+}$.

\begin{tabular}{|c|c|c|c|c|c|c|c|}
\hline Samples & $\begin{array}{l}\theta(001) \\
\text { reflection / } \\
\text { o }\end{array}$ & $\begin{array}{l}\theta(001) \\
\text { reflection } \\
\text { peak / }{ }^{\circ}\end{array}$ & $\begin{array}{l}\mathrm{d}_{(001)} \text { range } \\
/ \mathrm{nm}\end{array}$ & $\begin{array}{l}\mathrm{d}_{(001)} \\
\text { peak / } \\
\mathrm{nm}\end{array}$ & $\begin{array}{l}\text { Mass remain } \\
\text { at } 800^{\circ} \mathrm{C} / \\
\text { wt. } \%\end{array}$ & $\begin{array}{l}\text { Estimated } \\
\text { content of } \\
\mathrm{Ca}^{2+} \text { for } \\
\text { crosslinking } \\
\text { Alg / wt.\% }\end{array}$ & $\begin{array}{l}\text { Estimated } \\
\text { content of } \mathrm{Ca}^{2+} \\
\text { adsorbed onto } \\
\mathrm{Mt} / \mathrm{wt} . \%\end{array}$ \\
\hline Mt & $2.9 \sim 4.1$ & 3.5 & $1.52 \sim 1.08$ & 1.23 & 91.3 & - & - \\
\hline Alg & & - & & - & 27.7 & - & - \\
\hline $\mathrm{Ca}^{2+}-\mathrm{Alg}$ & & - & & - & 23.7 & 3.1 & - \\
\hline $\mathrm{Ca}^{2+}-\mathrm{Mt} 2 \mathrm{Alg} 8$ & $1.2 \sim 2.5$ & 1.6 & $1.77 \sim 3.67$ & 2.76 & 43.4 & 2.2 & 3.4 \\
\hline Mt3Alg7 & $1.8 \sim 3.2$ & 2.5 & $1.38 \sim 2.45$ & 1.77 & - & - & - \\
\hline $\mathrm{Ca}^{2+}-\mathrm{Mt} 3 \mathrm{Alg} 7$ & $1.2 \sim 3.1$ & 2.1 & $1.42 \sim 3.67$ & 2.10 & 50.8 & 1.9 & 4.3 \\
\hline $\mathrm{Ca}^{2+}-\mathrm{Mt} 5 \mathrm{Alg} 5$ & $1.3 \sim 3.0$ & 2.1 & $1.47 \sim 3.39$ & 2.10 & 60.9 & 1.4 & 2.9 \\
\hline
\end{tabular}

The Mt dispersion in the freeze-dried $\mathrm{Ca}^{2+}-\mathrm{MtAlg}$ nanocomposite films could be depicted by Figure 1 (a), Table 1 and Scheme 1 (a). According to Bragg's law (Bragg and Bragg, 1913), the distinctive peak reflection at $2 \theta=7.1^{\circ}$ of the neat Mt showed that its interlayer spacing, $\mathrm{d}_{001}$ peak value was $1.23 \mathrm{~nm}$ (Chen and Evans, 2004). Neither Alg nor $\mathrm{Ca}^{2+}$-Alg displayed any characteristic reflection from $2^{\circ}$ to $20^{\circ}$ because they did not contain any Mt. The Mt/Alg nanocomposites with or without $\mathrm{Ca}^{2+}$ showed a greater $\mathrm{d}_{001}$ value than that of the neat Mt. These results indicated that Alg chains were inserted into the interlayer space of Mt, forming intercalated nanostructure (Abdollahi et al., 2013; Alboofetileh et al., 2013; Liang et al., 2016). $\mathrm{Ca}^{2+}$-Mt2Alg8 displayed slightly a higher $\mathrm{d}_{001}$ peak value than those of Mt3Alg7, $\mathrm{Ca}^{2+}-\mathrm{Mt} 3 \mathrm{Alg} 7$ and $\mathrm{Ca}^{2+}-\mathrm{Mt5Alg} 5$, probably due to the higher Alg content of $\mathrm{Ca}^{2+}-\mathrm{Mt} 2 \mathrm{Alg} 8$. $\mathrm{Ca}^{2+}-\mathrm{Mt} 3 \mathrm{Alg} 7$ showed a slightly larger do01 peak value than Mt3Alg7, implying that the interlayer spacing of Mt layers in $\mathrm{Ca}^{2+}-\mathrm{MtAlg}$ was further expanded after fully swollen in $\mathrm{CaCl}_{2}$ solution. $\mathrm{Ca}^{2+}-\mathrm{Mt} 3 \mathrm{Alg} 7$ and $\mathrm{Ca}^{2+}-\mathrm{Mt5Alg} 5$ showed the same $\mathrm{d}_{001}$ peak value, indicating that the increase of $\mathrm{Mt} / \mathrm{Alg}$ mass ratio from 3:7 to 1:1 had no influence on the intercalation of $\mathrm{Alg}$ into $\mathrm{Mt}$ layers in the $\mathrm{Ca}^{2+}$-MtAlg nanocomposites. 
As seen from Figure 1 (b) and Scheme 1 (b), ample hydrogen bonds could form between Mt and Alg for MtAlg and $\mathrm{Ca}^{2+}-\mathrm{MtAlg}$. The peaks at $3290 \mathrm{~cm}^{-1}$ were characteristic for the C$\mathrm{OH}$ groups of Alg. For MtAlg and $\mathrm{Ca}^{2+}-\mathrm{MtAlg}$, this peak was suppressed compared to that of Alg because of hydrogen bonding between the $\mathrm{C}-\mathrm{OH}$ groups of $\mathrm{Alg}$ and the $\mathrm{Si}-\mathrm{O}$ groups of Mt surface (Kevadiya et al., 2010; Abdollahi et al., 2013; Mu et al., 2015; Liang et al., 2016). Besides, Mt edge could also interact with Alg, through hydrogen bonding between the hydroxyl groups on the Mt edge and carbonyl groups of Alg (Alboofetileh et al., 2013; Liang et al., 2016; Wu et al., 2016; Zlopasa et al., 2016). For Mt, the FTIR peak at $3625 \mathrm{~cm}^{-1}$ was characteristic for hydroxyl groups. This peak disappeared in $\mathrm{Ca}^{2+}-\mathrm{Mt} 2 \mathrm{Alg} 8$ and $\mathrm{Mt} 3 \mathrm{Alg} 7$, while it shifted to a lower wavenumber in $\mathrm{Ca}^{2+}-\mathrm{Mt} 3 \mathrm{Alg} 7$ and $\mathrm{Ca}^{2+}-\mathrm{Mt} 5 \mathrm{Alg} 5$. It was known from the previous work (Qiu et al., 2014) that the formation of Mt-Alg hydrogen bonding made the $-\mathrm{OH}$ peak of Mt shift to a lower wavenumber, and a high mass content of $\mathrm{Alg}(\geq$ $60 \%$ ) could make this peak disappear (Kevadiya et al., 2010). Meanwhile, there was a peak at $1590 \mathrm{~cm}^{-1}$ characteristic for $\mathrm{COO}^{-}$asymmetric stretch of Alg chains (Kevadiya et al., 2010; Qiu et al., 2014). This peak shifted to a higher wavenumber in Mt/Alg nanocomposites. These FTIR results confirm the formation of ample hydrogen bonds between Alg chains and Mt layers as shown in Scheme 1 (b) (Kevadiya et al., 2010; Qiu et al., 2014).

For Alg and MtAlg73, there was a peak at $1406 \mathrm{~cm}^{-1}$ which was characteristic for $\mathrm{COO}^{-}$ symmetric stretch of Alg chains (Lawrie et al., 2007; Sartori et al., 1997). When both asymmetric $\left(1590 \mathrm{~cm}^{-1}\right)$ and symmetric $\left(1406 \mathrm{~cm}^{-1}\right) \mathrm{COO}^{-}$peaks for $\mathrm{Ca}^{2+}-\mathrm{Alg}$ and $\mathrm{Ca}^{2+}-$ MtAlg shifted to higher wavenumbers, it indicated the ionic crosslinking and the formation of "egg-box" structure between $\mathrm{Ca}^{2+}$ and carboxyl groups of two neighbouring Alg chains (Sartori et al., 1997). As for the "egg-box" structure of G blocks, Alg chains were folded and formed a dense and hydrophobic part as shown in Scheme 1 (c) (Yu et al., 2009). Once $\mathrm{Ca}^{2+}$ was introduced to replace $\mathrm{Na}^{+}$of $\mathrm{Alg}$, the charge density, the radius and the atomic mass of 
the cations were altered so that a peak shift was detected (Daemi and Barikani, 2012; Sartori et al., 1997).

The presence of $\mathrm{Ca}^{2+}$ in $\mathrm{Ca}^{2+}-\mathrm{Alg}$ and $\mathrm{Ca}^{2+}-\mathrm{MtAlg}$ was confirmed by EDX as shown in Figure 1 (c-f). O, characteristic for Alg and Mt layers, was detected for all the samples. For $\mathrm{Ca}^{2+}-\mathrm{Alg}, \mathrm{Ca}^{2+}$ serving as the crosslinker of $\mathrm{Alg}$ was presented while Si characteristic for $\mathrm{Mt}$ layers was absent as expected. For $\mathrm{Ca}^{2+}-\mathrm{MtAlg}$, $\mathrm{Si}$ characteristic for Mt layers was also presented. The detected $\mathrm{Ca}^{2+}$ was due to $\mathrm{Ca}^{2+}$-Alg crosslinking and adsorption of $\mathrm{Ca}^{2+}$ onto Mt layers.

According to Figure $1(\mathrm{~g})$ and Table 1, Mt displayed a mass loss of $8.7 \%$ at $800{ }^{\circ} \mathrm{C}$ because of the loss of water inside the galleries and hydroxyl groups of crystalline lattices (Lagaly et al., 2006; Wu and Chen, 2014). The main residue of the decomposed Alg when heated to $700{ }^{\circ} \mathrm{C}$ was $\mathrm{Na}_{2} \mathrm{CO}_{3}$, showing a mass remain of $27.7 \%$ similar to the result previously reported (Soares et al., 2004). When it came to $\mathrm{Ca}^{2+}$-crosslinked $\mathrm{Alg}, \mathrm{CaO}$ was obtained as the remaining material when heated to $700{ }^{\circ} \mathrm{C}$ (Kong et al., 2009). Therefore, $\mathrm{Na}^{+} / \mathrm{Ca}^{2+}$ molar ratio of $\mathrm{Ca}^{2+}-\mathrm{Alg}$ could be determined as 4.6 and the mass content of $\mathrm{Ca}^{2+}$ in dry $\mathrm{Ca}^{2+}$-Alg was calculated to be $3.1 \%$ (Supplementary Materials). Similarly, the content of $\mathrm{Ca}^{2+}$ in dry $\mathrm{Ca}^{2+}-\mathrm{MtAlg}$ was also deducted. $\mathrm{Ca}^{2+}$ in $\mathrm{Ca}^{2+}-\mathrm{MtAlg}$ nanocomposite films came from not only the $\mathrm{Ca}^{2+}$-crosslinked $\mathrm{Alg}$ but also the $\mathrm{Ca}^{2+}$ adsorbed onto the Mt surface. $\mathrm{Ca}^{2+}$ was bound with Mt layers through either electrostatic interaction, or formation of a complex between $\mathrm{CaCl}^{+}$and the hydroxyl groups on the Mt surface (Brevik and Burgess, 2012; Rytwo et al., 1996). Mass fraction of $\mathrm{Ca}^{2+}$ for crosslinking $\mathrm{Alg}$ in the dry films was in the order of $\mathrm{Ca}^{2+}-\mathrm{Mt} 2 \mathrm{Alg} 8>\mathrm{Ca}^{2+}-\mathrm{Mt} 3 \mathrm{Alg} 7>\mathrm{Ca}^{2+}-\mathrm{Mt} 5 \mathrm{Alg} 5$, which was proportional to the Alg mass content. However, mass fraction of $\mathrm{Ca}^{2+}$ adsorbed onto Mt layers in the dry films was in the order of $\mathrm{Ca}^{2+}-\mathrm{Mt} 3 \mathrm{Alg} 7>\mathrm{Ca}^{2+}-\mathrm{Mt} 2 \mathrm{Alg} 8>\mathrm{Ca}^{2+}-\mathrm{Mt} 5 \mathrm{Alg} 5$, in which $\mathrm{Ca}^{2+}-\mathrm{Mt} 5 \mathrm{Alg} 5$ with the highest Mt mass content displayed the lowest $\mathrm{Ca}^{2+}$ adsorption. This was probably because the 
high content of Mt layers in Mt5Alg5 stacked more closely than those in Mt3Alg7 and thus the diffusion of $\mathrm{Ca}^{2+}$ was impeded during submersion in $\mathrm{CaCl}_{2}$ solution.

The microstructure of freeze-dried $\mathrm{Ca}^{2+}$-crosslinked hydrogel films could be observed by SEM in Figure $1(\mathrm{~h}-\mathrm{k})$. On the cross-sectional surface of $\mathrm{Ca}^{2+}-\mathrm{Alg}$, there were highly dense layers of $\mathrm{Ca}^{2+}$-crosslinked Alg shown as dark blocks, and loosely contacted and unconnected Alg chains shown as bright threads. This feature resulted from polymer folding and separate phases of polymer layers, forming inhomogeneous microstructure by the means of external gelation (Al-Remawi, 2012).

When it came to $\mathrm{Ca}^{2+}-\mathrm{Mt} 2 \mathrm{Alg} 8$, there were no obvious loose polymer threads because of the adsorption of Alg chains onto Mt layers by montmorillonite edge-Alg electrostatic interaction and hydrogen bonding (Abdollahi et al., 2013; Zlopasa et al., 2015). As with a previous research (Abdollahi et al., 2013), the smoothness of the surface reduced with the incorporation of Mt layers.

As for $\mathrm{Ca}^{2+}-\mathrm{Mt} 3 \mathrm{Alg} 7$ and $\mathrm{Ca}^{2+}-\mathrm{Mt5} \mathrm{Alg} 5$, with the enhanced Mt content compared to that of $\mathrm{Ca}^{2+}-\mathrm{Mt} 2 \mathrm{Alg} 8$, typical nacre-like structure with ordered alignment of Mt chunks was displayed, confirming that with a high Mt mass content $\geq 20 \%$, Alg is capable of forming nacre-like microstructure by solution casting method (Liang et al., 2016; Zlopasa et al., 2015). Unlike the previously reported $\mathrm{Mt} / \mathrm{Alg} / \mathrm{Ca}^{2+}$ nanocomposite films (Liang et al., 2016) which displayed dense alignment, there were some pores embedded in between the orientated lamellae of $\mathrm{Ca}^{2+}-\mathrm{Mt} 3 \mathrm{Alg} 7$ because it was fully swollen in water, forming $\mathrm{Ca}^{2+}$-crosslinked hydrogels before freeze-drying. After freeze-drying, porous structure was preserved like some other dehydrated $\mathrm{Ca}^{2+}-\mathrm{Alg}$ hydrogels without Mt reported in the literature (de Moura et al., 2005).

Comparing $\mathrm{Ca}^{2+}-\mathrm{Mt5} \mathrm{Alg} 5$ with $\mathrm{Ca}^{2+}-\mathrm{Mt} 3 \mathrm{Alg} 7$, the former displayed significant pull-out of Mt chunks which was common in many nacre-mimicking materials (Das et al., 2015) 
while the latter did not. This implied that some Mt layers on the fracture surface of $\mathrm{Ca}^{2+}$ Mt5Alg5 were pulled out when the samples were fractured in liquid nitrogen (Hao et al., 2016). At a high content of clay mineral, when the clay mineral aspect ratio was lower than 1000 and polymer chains were interlocked with Mt layers, nacre-mimicking materials tended to break in this "pull-out" way (Das et al., 2015; Hao et al., 2016). However, $\mathrm{Ca}^{2+}-\mathrm{Mt} 3 \mathrm{Alg} 7$ only had a few pull-out layers. This was originated from the chemical composition, which could be confirmed by thermogravimetric analysis and swelling tests. On one hand, the water mass percentages in the fully swollen $\mathrm{Ca}^{2+}-\mathrm{Mt} 3 \mathrm{Alg} 7$ and $\mathrm{Ca}^{2+}-\mathrm{Mt} 5 \mathrm{Alg} 5$ were known as 0.27 and 0.35 , respectively. Like many nanocomposite hydrogels, as the polymer chains were extended and the crosslinking density reduced during swelling, the swollen nanocomposite hydrogels became weak ( $\mathrm{Su}$ et al., 2017). So due to the low water content of $\mathrm{Ca}^{2+}-\mathrm{Mt} 3 \mathrm{Alg} 7$ nanocomposite hydrogel films, they were mechanically stronger than $\mathrm{Ca}^{2+}-\mathrm{Mt} 5 \mathrm{Alg} 5$, impeding the Mt pull-out. On the other hand, from Figure $1(\mathrm{~g})$, Table 1 and Supplementary Materials, the mass ratios of $\mathrm{Alg}$ chains " $\left(\mathrm{C}_{6} \mathrm{H}_{7} \mathrm{O}_{6}\right)_{n}$ ", $\mathrm{Mt}$ layer of "Na0.41 $\mathrm{Al}_{3.53} \mathrm{Mg}_{0.46} \mathrm{Si}_{8} \mathrm{O}_{20}(\mathrm{OH}) 4$ " and $\mathrm{Ca}^{2+}$ for $\mathrm{Ca}^{2+}-\mathrm{Mt} 3 \mathrm{Alg} 7$ and $\mathrm{Ca}^{2+}-\mathrm{Mt} 5 \mathrm{Alg} 5$ calculated from TGA were 8.76:2.46:1 and 9.52:6.25:1, respectively. Comparing $\mathrm{Ca}^{2+}$-Mt3Alg7 and $\mathrm{Ca}^{2+}-\mathrm{Mt5Alg} 5$, the higher $\mathrm{Ca}^{2+} / \mathrm{Mt}$ ratio of the former resulted in a stronger $\mathrm{Ca}^{2+}-\mathrm{Mt}$ electrostatic interaction and higher crosslinking density, improving the mechanical properties and hindering the Mt pull-out. Besides, the former might have more Mt edge-Alg electrostatic bonds and Mt-Alg hydrogen bonds due to its lower Mt/Alg ratio, also increasing the crosslinking density and inhibiting the Mt pull-out (Yao et al., 2017).

Besides, there was no obvious porous structure found in $\mathrm{Ca}^{2+}-\mathrm{Mt} 5 \mathrm{Alg} 5$ and its microstructure was relatively compact compared to that of $\mathrm{Ca}^{2+}-\mathrm{Mt} 3 \mathrm{Alg} 7$. This was probably due to the higher Mt content of $\mathrm{Ca}^{2+}-\mathrm{Mt} 5 \mathrm{Alg} 5$ than that of $\mathrm{Ca}^{2+}-\mathrm{Mt} 3 \mathrm{Alg} 7$. In $\mathrm{Ca}^{2+}-\mathrm{Mt} 5 \mathrm{Alg} 5$, because of the higher Mt content, the interaction between the adjacent Mt layers was higher 
than that in $\mathrm{Ca}^{2+}-\mathrm{Mt} 3 \mathrm{Alg}$. Therefore, despite of using a freeze-drying process, the freezedried $\mathrm{Ca}^{2+}-\mathrm{Mt} 5 \mathrm{Alg} 5$ failed to keep the porous structure of the $\mathrm{Ca}^{2+}$-crosslinked hydrogels, unlike $\mathrm{Ca}^{2+}-\mathrm{Mt} 3 \mathrm{Alg} 7$, but showed more ordered and compact structure instead (Das et al., 2017).

\subsection{Mechanical properties of $\mathrm{Ca}^{2+}-\mathrm{MtAlg}$ nanocomposites}

The mechanical properties and swelling behavours of $\mathrm{Ca}^{2+}-\mathrm{Mt} 2 \mathrm{Alg} 8, \mathrm{Ca}^{2+}-\mathrm{Mt} 3 \mathrm{Alg} 7$ and $\mathrm{Ca}^{2+}-\mathrm{Mt} 5 \mathrm{Alg} 5$ were shown in Figure 2 (a) and Table 2, respectively.
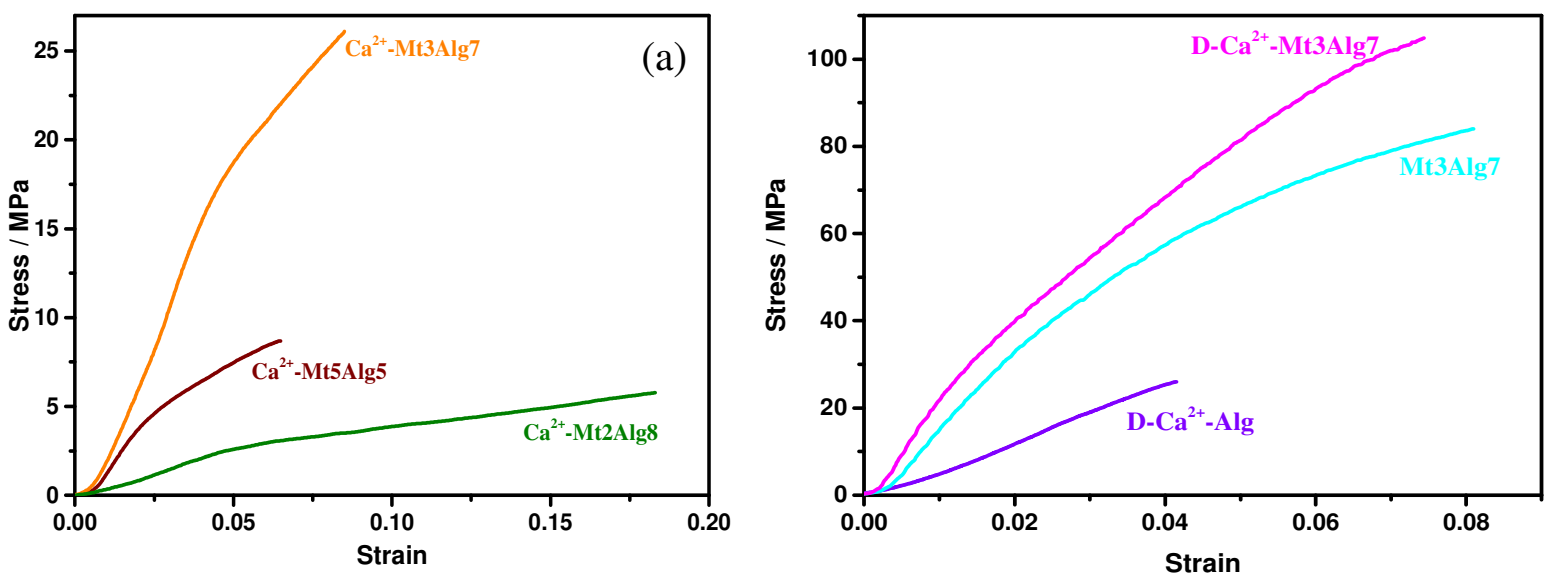

(c)

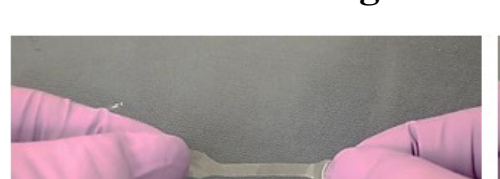

\section{$\mathrm{Ca}^{2+}=\mathrm{Mt} 2 \mathrm{Alg8}$}

(d)

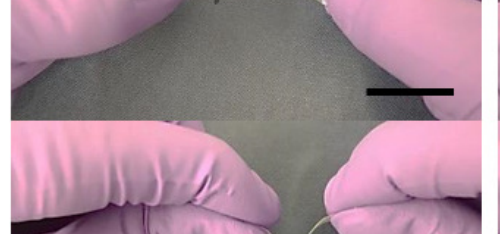

d)

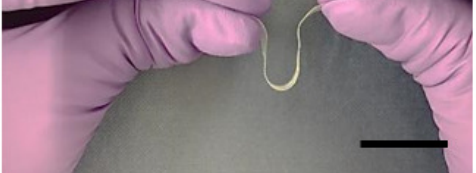

(e)

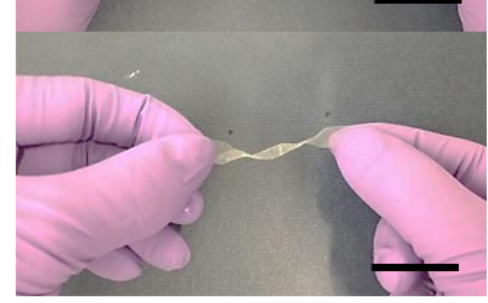

$\mathrm{Ca}^{2+}$-Mt3Alg7

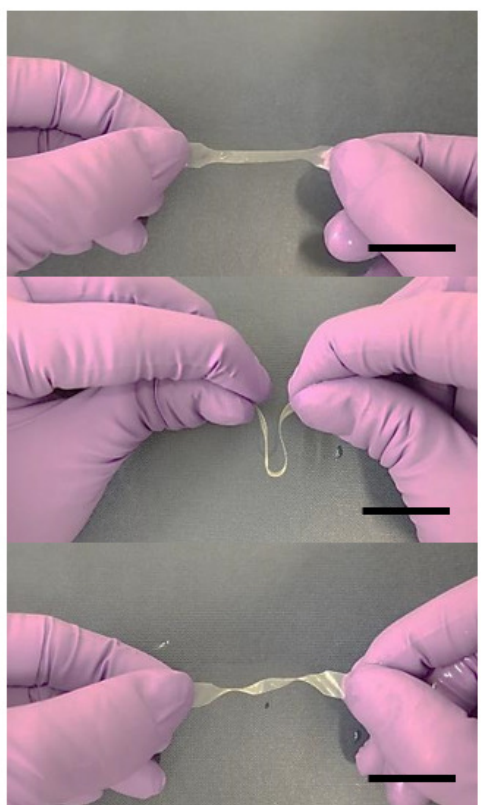

$\mathrm{Ca}^{2+}=\mathrm{Mt5}$ Alg5

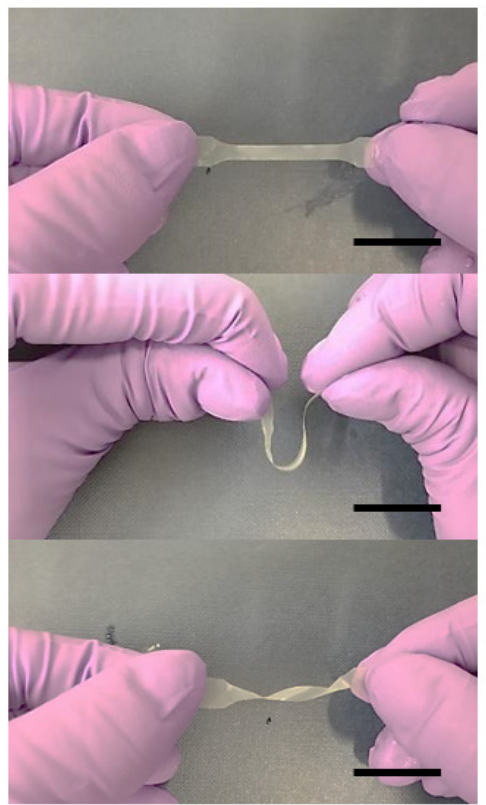


Fig. 2. Typical tensile stress-strain curves of the (a) hydrated films and (b) dry films, (c) the as-prepared samples could withstand (d) bending, and (e) twisting without permanent deformation. (scale bar: $25 \mathrm{~mm}$ )

Table 2. Tensile properties of the swollen and dry nanocomposite films

\begin{tabular}{lllllc}
\hline Samples & $\begin{array}{l}\text { Young's } \\
\text { modulus / } \\
\mathrm{MPa}\end{array}$ & $\begin{array}{l}\text { Tensile } \\
\text { strength / MPa }\end{array}$ & $\begin{array}{l}\text { Strain at } \\
\text { break }\end{array}$ & $\begin{array}{l}\text { Toughness } \\
/ \mathrm{MJ} \mathrm{m}^{-3}\end{array}$ & $\begin{array}{l}\text { Equilibrium } \\
\text { swelling } \\
\text { ratio / } \varphi\end{array}$ \\
\hline $\mathrm{Ca}^{2+}$-Mt5Alg5 & $277 \pm 27$ & $9.3 \pm 0.3$ & $0.07 \pm 0.01$ & $0.38 \pm 0.12$ & $0.55 \pm 0.03$ \\
\hline $\mathrm{Ca}^{2+}-\mathrm{Mt} 3 \mathrm{Alg} 7$ & $412 \pm 16$ & $28 \pm 1.0$ & $0.10 \pm 0.01$ & $1.8 \pm 0.4$ & $0.37 \pm 0.01$ \\
\hline $\mathrm{Ca}^{2+}-\mathrm{Mt} 2 \mathrm{Alg} 8$ & $58 \pm 2$ & $5.8 \pm 0.1$ & $0.20 \pm 0.01$ & $0.69 \pm 0.03$ & $0.62 \pm 0.02$ \\
\hline $\mathrm{D}-\mathrm{Ca}^{2+}-\mathrm{Alg}$ & $670 \pm 30$ & $24 \pm 2$ & $0.03 \pm 0.01$ & $0.50 \pm 0.02$ & - \\
\hline $\mathrm{Mt} 3 \mathrm{Alg} 7$ & $2080 \pm 90$ & $85 \pm 5$ & $0.09 \pm 0.01$ & $4.3 \pm 0.4$ & - \\
\hline $\mathrm{D}-\mathrm{Ca}^{2+}-\mathrm{Mt} 3 \mathrm{Alg} 7$ & $2650 \pm 140$ & $101 \pm 7$ & $0.06 \pm 0.01$ & $4.8 \pm 0.2$ & - \\
\hline
\end{tabular}

As seen from Figure 2 (a, c-e), even fully swollen, $\mathrm{Ca}^{2+}$-MtAlg nanocomposite films were very stable, strong and flexible. The swelling ratios of the films displayed an inverse order as $\mathrm{Ca}^{2+}-\mathrm{Mt} 3 \mathrm{Alg} 7>\mathrm{Ca}^{2+}-\mathrm{Mt} 5 \mathrm{Alg} 5>\mathrm{Ca}^{2+}-\mathrm{Mt} 2 \mathrm{Alg} 8$ in Table 2. The films displayed a low strain at break no more than 0.20 . As for the swelling ratio, it was in the same order as that of mass fraction of the $\mathrm{Ca}^{2+}$ adsorbed onto Mt layers, indicating that these adsorbed $\mathrm{Ca}^{2+}$ dominated the swelling behaviour of $\mathrm{Ca}^{2+}$-MtAlg. In terms of mechanical properties, with incorporation of $30 \mathrm{wt} \% \mathrm{Mt}$, the swollen nanocomposite hydrogel films could reach a Young's modulus of $412 \mathrm{MPa}$ and a tensile strength of $28 \mathrm{MPa}$, which were significantly higher than those of films with 20 wt.\% or 50 wt.\% of Mt. $\mathrm{Ca}^{2+}{ }_{-} \mathrm{Mt} 3 \mathrm{Alg} 7$ displayed remarkably distinctive mechanical properties from those of $\mathrm{Ca}^{2+}-\mathrm{Mt} 2 \mathrm{Alg} 8$ and $\mathrm{Ca}^{2+}-\mathrm{Mt5} \mathrm{Alg} 5$. This was closely related to the microstructure discussed below. Fully swollen $\mathrm{Ca}^{2+}$-Alg films were not tested because they were too weak to test. Comparing the fully swollen films with or without the incorporation of Mt suggested that even after full swelling, the in situ crosslinked Alg network helped to preserve montmorillonite edge-Alg electrostatic interaction and ample Mt-Alg hydrogen bonds, despite the electrorepulsion between negatively charged Alg chains and Mt surfaces as mentioned before (Liang et al., 2016; Zlopasa et al., 2015). Unlike the brittle $\mathrm{Ca}^{2+}$-Alg ionic network of $\mathrm{Ca}^{2+}-\mathrm{Alg}$ (Sun et al., 2012), 
the montmorillonite edge-Alg electrostatic bonds and ample Mt-Alg hydrogen bonds in $\mathrm{Ca}^{2+}$ MtAlg nanocomposite hydrogel films increased the crosslinking density strengthening the nanocomposite hydrogel films (Wu et al., 2016). Besides, $\mathrm{Ca}^{2+}-\mathrm{Mt}$ electrostatic interaction also played an important role in the mechanical properties of $\mathrm{Ca}^{2+}$-MtAlg nanocomposite hydrogel films.

Comparing $\mathrm{Ca}^{2+}-\mathrm{Mt} 3 \mathrm{Alg} 7$ with $\mathrm{Ca}^{2+}-\mathrm{Mt} 2 \mathrm{Alg} 8$, on one hand, the former displayed an over 6-fold higher Young's modulus and nearly 4 times higher tensile strength than the latter. First, the lower swelling ratio of $\mathrm{Ca}^{2+}-\mathrm{Mt} 3 \mathrm{Alg} 7$ also contributed to the higher Young's modulus and tensile strength because water softened polymer chains and reduced the mechanical performance for clay mineral-polymer nanocomposite films (Wu and Chen, 2014; Wu et al., 2014). Secondly, when positively charged $\mathrm{Ca}^{2+}$ were adsorbed onto the negatively charged Mt layers, they interacted by the electrostatic attraction. So when a higher amount of $\mathrm{Ca}^{2+}$ was adsorbed onto $\mathrm{Mt}$ in $\mathrm{Ca}^{2+}-\mathrm{Mt} 3 \mathrm{Alg} 7$, the electrostatic attraction increased and led to an enhanced crosslinking density, Young's modulus and tensile strength (Segad et al., 2010). Thirdly, the higher Mt/Alg mass ratio of $\mathrm{Ca}^{2+}-\mathrm{Mt} 3 \mathrm{Alg} 7$ might provide more montmorillonite edge-Alg electrostatic bonds and Mt-Alg hydrogen bonds than that of $\mathrm{Ca}^{2+}-\mathrm{Mt} 2 \mathrm{Alg} 8$, further increasing the crosslinking density as well as its mechanical performance. On the other hand, $\mathrm{Ca}^{2+}-\mathrm{Mt} 3 \mathrm{Alg} 7$ displayed half of the strain at break of $\mathrm{Ca}^{2+}-\mathrm{Mt} 2 \mathrm{Alg} 8$ due to its lower content of flexible Alg chains and higher crosslinking density in the nanocomposite hydrogel film.

Comparing $\mathrm{Ca}^{2+}-\mathrm{Mt} 3 \mathrm{Alg} 7$ with $\mathrm{Ca}^{2+}-\mathrm{Mt5} \mathrm{Alg} 5$, the former displayed higher Young's modulus, tensile strength and strain at break. As discussed before, the higher swelling ratio of $\mathrm{Ca}^{2+}-\mathrm{Mt} 5 \mathrm{Alg} 5$ deteriorated the mechanical properties compared to those of $\mathrm{Ca}^{2+}-\mathrm{Mt} 3 \mathrm{Alg} 7$. Also while the Mt content was higher, the reduced content of $\mathrm{Ca}^{2+}$ adsorbed onto Mt layers in $\mathrm{Ca}^{2+}-\mathrm{Mt} 5 \mathrm{Alg} 5$ declined its crosslinking density and mechanical properties compared to those of $\mathrm{Ca}^{2+}-\mathrm{Mt} 3 \mathrm{Alg} 7$. 
In comparison, after being immersed in water for a period, Mt3Alg7 films and AMt3Alg7Gly1.75 films were mostly dissolved. $\mathrm{Ca}^{2+}-\mathrm{Mt} 3 \mathrm{Alg} 97$ and L-Mt3Alg7-Ca ${ }^{2+}$ films were insoluble in water and only swelled. The latter two became as weak as wet paper and could not be tensile tested. These phenomena could be attributed to the absence of ionic crosslinking by $\mathrm{Ca}^{2+}$ in Mt3Alg7 and A-Mt3Alg7Gly1.75, the low Mt content in $\mathrm{Ca}^{2+}$ Mt3Alg97 and the different synthetic method of $\mathrm{L}_{-} \mathrm{Ca}^{2+}-\mathrm{Mt} 3 \mathrm{Alg}$. As for $\mathrm{L}-\mathrm{Ca}^{2+}-\mathrm{Mt} 3 \mathrm{Alg} 7$, vacuum filtration was used for preparation, which tended to give rise to a denser alignment of Mt layers than those prepared by solution casting (Yao et al., 2010). Despite its compact microstructure, $\mathrm{L}-\mathrm{Ca}^{2+}-\mathrm{Mt} 3 \mathrm{Alg} 7$ was obtained from prior crosslinked Alg slurry, rather than by in situ crosslinking of $\mathrm{Alg}$ by $\mathrm{Ca}^{2+}$ with the presence of aligned Mt layers in the case of $\mathrm{Ca}^{2+}$-MtAlg nanocomposite films that led to a continuously crosslinked and more homogeneous network. So when fully swollen, it was likely for the more homogeneous network in $\mathrm{Ca}^{2+}$-MtAlg to work better in stabilising the network and showing superior mechanical properties than the physically compressed laminae in $\mathrm{L}_{-} \mathrm{Ca}^{2+}-\mathrm{Mt} 3 \mathrm{Alg} 7$.

In order to further understand the relation between the microstructure and the mechanical properties of $\mathrm{Ca}^{2+}-\mathrm{MtAlg}$ nanocomposite films, some relevant dry materials including Mt3Alg7, D-Ca ${ }^{2+}-\mathrm{Alg}$ and D-Ca ${ }^{2+}-\mathrm{Mt} 3 \mathrm{Alg} 7$ were investigated.

As seen from Figure 2 (b) and Table 2, D-Ca ${ }^{2+}-\mathrm{Mt} 3 \mathrm{Alg} 7$ behaved like many other nacrelike materials with a high Young's modulus and a low strain at break (Liang et al., 2016; Podsiadlo et al., 2007; Yao et al., 2010). Comparing D-Ca ${ }^{2+}-\mathrm{Alg}$ with either Mt3Alg7 or D$\mathrm{Ca}^{2+}-\mathrm{Mt} 3 \mathrm{Alg} 7$, the incorporation of Mt significantly increased the mechanical properties including Young's modulus, tensile strength and strain at break. Stiff Mt layers (Chen and Evans, 2006) were known to effectively enhance Young's modulus of clay mineral/polymer nanocomposites. With the efficient load transfer from Alg matrix to Mt layers by Mt edgeAlg electrostatic interaction, Mt-Alg hydrogen bonding and continuously $\mathrm{Ca}^{2+}$ crosslinked 
Alg chains in the presence of Mt layers (Liang et al., 2016; Zlopasa et al., 2015), significant strengthening effect of Mt layers was presented like the previously reported Mt/Alg nanocomposites (Abdollahi et al., 2013; Alboofetileh et al., 2013; Liang et al., 2016). Comparing D-Ca ${ }^{2+}-\mathrm{Mt} 3 \mathrm{Alg} 7$ with Mt3Alg7, the former displayed a 27\% higher Young's modulus, $19 \%$ higher tensile strength and lower strain at break, confirming that the incorporation of $\mathrm{Ca}^{2+}$ strengthened the material by crosslinking $\mathrm{Alg}$ and interacting with $\mathrm{Mt}$ layers electrostatically (Liang et al., 2016; Segad et al., 2010; Sun et al., 2012). Compared to L-Ca ${ }^{2+}-\mathrm{Mt} 3 \mathrm{Alg} 7$ at the same Mt loading and with a tensile strength of $240 \mathrm{MPa}$ and an energy at break of $6 \mathrm{MJ} \mathrm{m}^{-3}$ (Liang et al., 2016), D-Ca ${ }^{2+}-\mathrm{Mt} 3 \mathrm{Alg} 7$ showed a lower tensile strength and energy at break. This was due to the more compact microstructure of $\mathrm{L}_{-} \mathrm{Ca}^{2+}-$ Mt3Alg7 originated from the different processing methods as discussed before.

In summary, the fully swollen $\mathrm{Ca}^{2+}-\mathrm{MtAlg}$ nanocomposite hydrogel films prepared in this work displayed an incredibly high Young's modulus up to $412 \mathrm{MPa}$ and a tensile strength up to $28 \mathrm{MPa}$. To the authors' knowledge, the mechanical properties of fully swollen clay mineral/Alg nanocomposites have never been reported before, because they were either partially soluble in water or too weak to mechanically test (Abdollahi et al., 2013; Alboofetileh et al., 2013; Liang et al., 2016; Vale et al., 2005). Apart from Mt/Alg nanocomposites, the tensile strength of fully swollen $\mathrm{Ca}^{2+}-\mathrm{Mt} 3 \mathrm{Alg} 7$ was also higher than that of some wet films reported before such as L-3,4-dihydroxyphenylalanine crosslinked chitosan immersed in phosphate buffered saline solution for $3 \mathrm{~h}$ (18 $\mathrm{MPa}$ ) (Oh and Hwang, 2013), and chitosan-cellulose nanofibril nanocomposite films swollen in distilled water (12 MPa) (Wu et al., 2014). The high tensile strength of fully swollen $\mathrm{Ca}^{2+}-\mathrm{Mt} 3 \mathrm{Alg} 7$ was attributed to the low equilibrium swelling ratio, optimal chemical composition, high crosslinking density, montmorillonite edge-Alg electrostatic interaction, ample Mt-Alg hydrogen bonds, strong $\mathrm{Ca}^{2+}-\mathrm{Mt}$ interaction and its aligned microstructure. $\mathrm{Ca}^{2+}$-MtAlg 
nanocomposite hydrogel films with excellent mechanical properties would be promising in the load-bearing aquatic applications, such as artificial membranes and tissue repair/reconstruction (Alboofetileh et al., 2013; Liang et al., 2016; Vale et al., 2005).

\subsection{Optical properties of $\mathrm{Ca}^{2+}-\mathrm{Alg}$ and $\mathrm{Ca}^{2+}-\mathrm{MtAlg}$ nanocomposite films}

As-prepared swollen $\mathrm{Ca}^{2+}-\mathrm{Alg}$ and $\mathrm{Ca}^{2+}-\mathrm{MtAlg}$ films with a thickness of 50-77 $\mu \mathrm{m}$ were tested by recording the transmittance within the range $250-800 \mathrm{~nm}$ as shown in Figure 3 (a) and Table S1 (See Supplementary Materials, Page S6, Table S1).
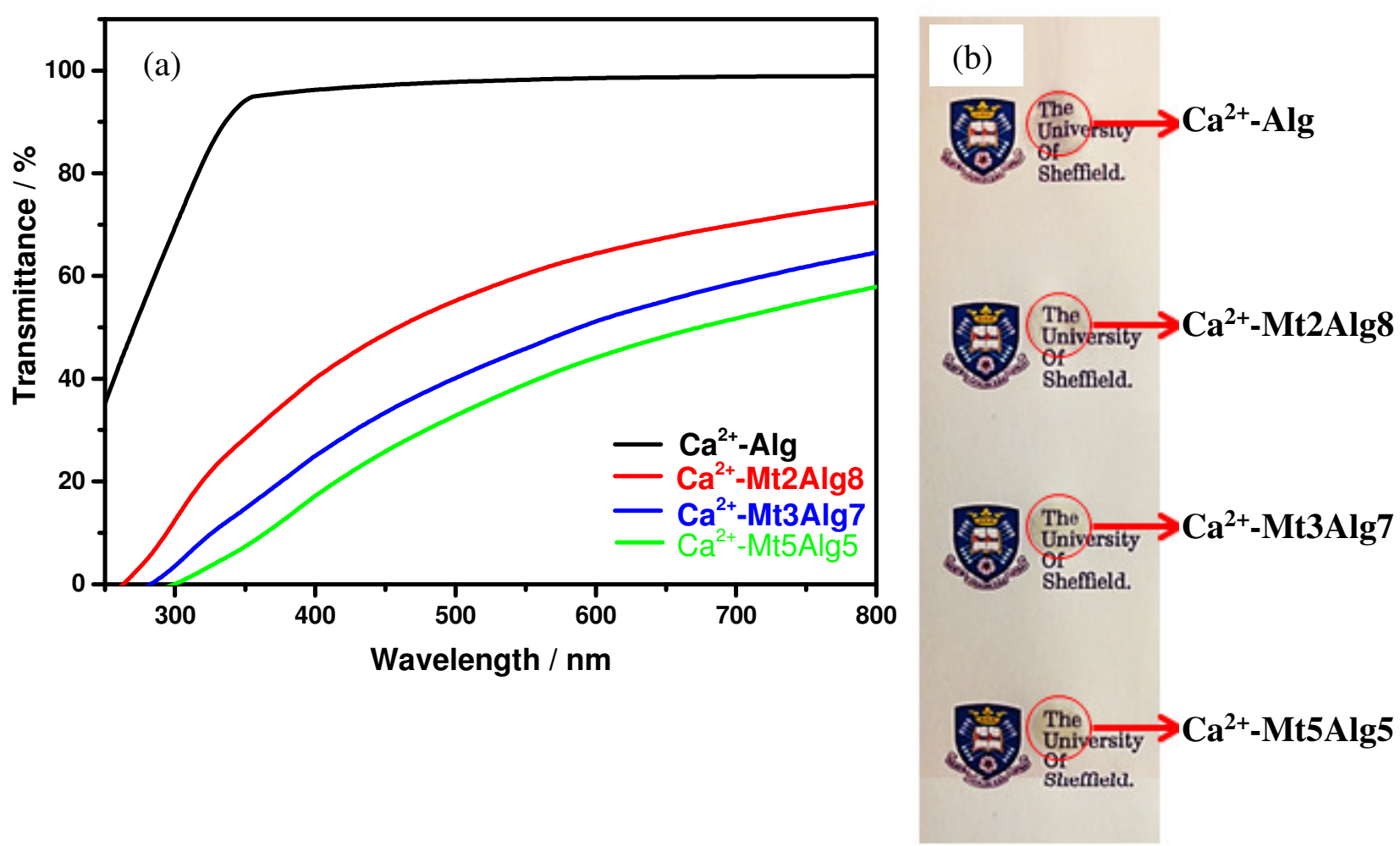

Fig. 3. (a) UV-Vis spectra of $\mathrm{Ca}^{2+}-\mathrm{Alg}$ and $\mathrm{Ca}^{2+}-\mathrm{MtAlg}$ films, and (b) image shows clearly the University of Sheffield logo beneath the circular $\mathrm{Ca}^{2+}-\mathrm{Alg}$ and $\mathrm{Ca}^{2+}-\mathrm{MtAlg}$ films highlighted by red circles.

Like some previously reported Mt/Alg nanocomposite films (Alboofetileh et al., 2013; Tezcan et al., 2012), $\mathrm{Ca}^{2+}$-MtAlg nanocomposite hydrogel films could effectively reduce the transmittance of UV light. At the wavelength of $400 \mathrm{~nm}, \mathrm{Ca}^{2+}-\mathrm{Alg}$ had a fairly high transmittance of $96.2 \%$ while $\mathrm{Ca}^{2+}-\mathrm{MtAlg}$ had a significant blocking effect to the light. At the 
wavelength of $320 \mathrm{~nm}, \mathrm{Ca}^{2+}-\mathrm{Mt} 3 \mathrm{Alg} 7$ and $\mathrm{Ca}^{2+}-\mathrm{Mt5} \mathrm{Alg} 5$ displayed a fairly low light transmittance of $8.6 \%$ and $2.8 \%$ respectively, while $\mathrm{Ca}^{2+}$-Alg could still let $82.2 \%$ of light go through. This was due to the blocking effect of the Mt-Alg phases with the lateral dimension larger than $400 \mathrm{~nm}$, implying that $\mathrm{Ca}^{2+}-\mathrm{MtAlg}$ films were effective in blocking ultraviolet light (wavelength $\leq 400 \mathrm{~nm}$ ). It is known that solar ultraviolet radiation is harmful to human and animal skin (Armstrong and Kricker, 2001; de Gruijl et al., 2001; Ichihashi et al., 2003). Especially, ultraviolet B with a wavelength from $290 \mathrm{~nm}$ to $320 \mathrm{~nm}$ is more responsible to mutation and skin cancer than ultraviolet A with a wavelength from $320 \mathrm{~nm}$ to $400 \mathrm{~nm}$ (Ichihashi et al., 2003). So combined with the biocompatibility of Alg (Kim et al., 2011), $\mathrm{Ca}^{2+}-\mathrm{MtAlg}$ could be promising in the applications of UV-proof skin care.

As seen from Figure 3 (b), the text "The University" underneath $\mathrm{Ca}^{2+}$-MtAlg films could be still seen clearly. Because the length of Mt single layers as well as intercalated clay mineral tactoids (mostly in the range of 40-280 nm) (Chen and Evans, 2004; Chen and Evans, 2006; Su and Chen, 2018) were mostly smaller than the wavelength of visible light (400-700 $\mathrm{nm}), \mathrm{Ca}^{2+}-\mathrm{MtAlg}$ nanocomposite films with intercalated and/or exfoliated Mt layers did not have a big blocking effect on the visible light passage (Abdollahi et al., 2013; Alboofetileh et al., 2013; Liang et al., 2016; Tezcan et al., 2012). At the wavelength of $800 \mathrm{~nm}, \mathrm{Ca}^{2+}-\mathrm{Alg}$ was highly transparent with a high light transmittance of $98.9 \%$ while the light transmittance decreased as the Mt content increased. This was quite common in Alg nanocomposite films (Abdollahi et al., 2013; Alboofetileh et al., 2013; Tezcan et al., 2012). The in situ crosslinked Alg network and ample Mt-Alg hydrogen bonds brought in large continuous Mt/Alg phases. Some of Mt/Alg phases were of large dimension reaching the wavelength of visible light and thus caused the reduced transparency (Liang et al., 2016; Rhim, 2011). 


\subsection{Solvent sensitivity}

Alg, with a high polarity and high molecular weight, is insoluble in alcohols or acetone, and it can only be dissolved in water (Pawar and Edgar, 2012). As the methanol-water or acetone-water binding force is higher than alginate-water binding force, either methanol or acetone tends to extract water from $\mathrm{Ca}^{2+}$-crosslinked Alg hydrogels, resulting in significant shape responsivities of the hydrogels to alcohols or acetone (Lee and Mooney, 2012; Mu et al., 2015; Wan et al., 1992). The solvent-sensitivity tests in methanol and acetone were conducted and the results were shown in Figure 4 (a-f).
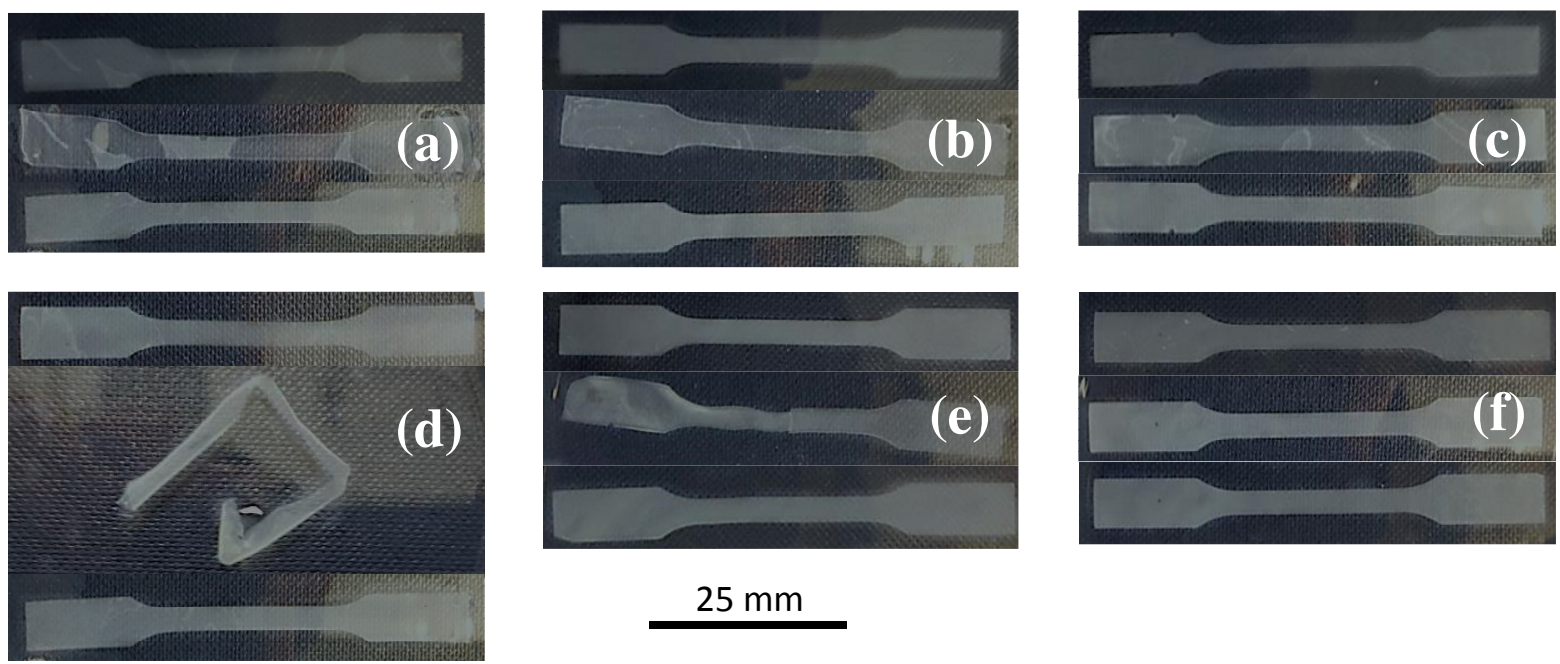

$25 \mathrm{~mm}$

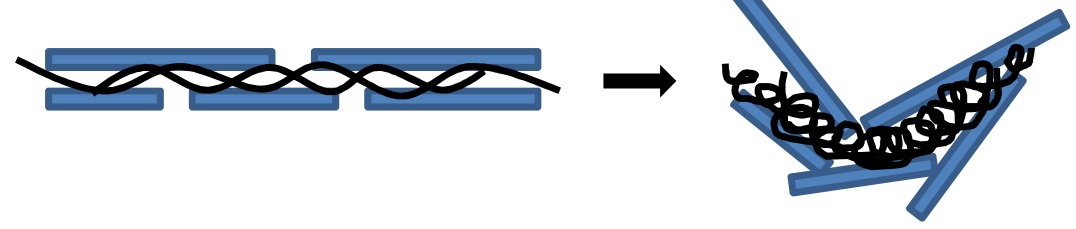

(g)

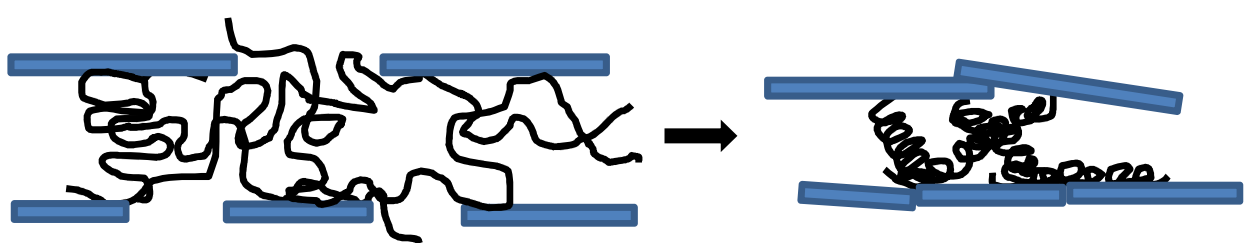

(h)

Fig. 4. Solvent-sensitive behaviours of $\mathrm{Ca}^{2+}-\mathrm{MtAlg}$ in methanol or acetone: (a) $\mathrm{Ca}^{2+}$ Mt2Alg8, (b) $\mathrm{Ca}^{2+}-\mathrm{Mt} 3 \mathrm{Alg} 7$ and (c) $\mathrm{Ca}^{2+}-\mathrm{Mt} 5 \mathrm{Alg} 5$, (top) fully swollen in water, (middle) then put in methanol for $24 \mathrm{~h}$, and (bottom) put back in water for another $4 \mathrm{~h}$; (d) $\mathrm{Ca}^{2+}$ Mt2Alg8, (e) $\mathrm{Ca}^{2+}-\mathrm{Mt} 3 \mathrm{Alg} 7$ and (f) $\mathrm{Ca}^{2+}-\mathrm{Mt5Alg} 5$, (top) fully swollen in water, (middle) then put in acetone for $24 \mathrm{~h}$ and (bottom) put back in water for another $4 \mathrm{~h}$; and schematic illustration of dehydration of (g) L-Ca ${ }^{2+}-\mathrm{Mt} 3 \mathrm{Alg} 7$, and (h) $\mathrm{Ca}^{2+}-\mathrm{MtAlg}$. 
From Figure $4(\mathrm{a}-\mathrm{c})$, it was discovered that for methanol-treated $\mathrm{Ca}^{2+}-\mathrm{MtAlg}$, the films were dehydrated slightly without obviously changing the shape. $\mathrm{Ca}^{2+}-\mathrm{Mt} 2 \mathrm{Alg} 8$ slightly curved on the edges while $\mathrm{Ca}^{2+}-\mathrm{Mt} 3 \mathrm{Alg} 7$ and $\mathrm{Ca}^{2+}-\mathrm{Mt} 5 \mathrm{Alg} 5$ hardly changed their shape. This was different from the previous result (Liang et al., 2016), in which significant shape change was observed by the $\mathrm{L}-\mathrm{Ca}^{2+}-\mathrm{Mt} 3 \mathrm{Alg} 7$ films. The reason for the different solvent sensitivity could be attributed to the different microstructure as illustrated in Figure 4 ( $\mathrm{g} \& \mathrm{~h}$ ). Because of the dense alignment of Mt layers by vacuum filtration (Yao et al., 2010), the movement of Alg chains in $\mathrm{L}-\mathrm{Ca}^{2+}-\mathrm{Mt} 3 \mathrm{Alg} 7$ was highly restricted by Mt layers. Once the interlayer water was removed by methanol, Alg chains coiled, carrying Mt layers to reorient. However, as for $\mathrm{Ca}^{2+}-\mathrm{MtAlg}$ nanocomposite hydrogel films, because the microstructure derived by solution casting and full swelling was less dense than that of $\mathrm{L}_{-} \mathrm{Ca}^{2+}-\mathrm{Mt} 3 \mathrm{Alg} 7$, the long free $\mathrm{Alg}$ chains in between the adjacent Mt layers coiled without the reorientation of Mt layers and gave rise to a much smaller shape change. Therefore, $\mathrm{Ca}^{2+}-\mathrm{MtAlg}$ nanocomposite hydrogel films displayed better shape stability when in contact with methanol than L-Ca ${ }^{2+}-\mathrm{Mt} 3 \mathrm{Alg} 7$.

When it came to acetone, as shown in Figure 4 (d-f), the films were highly dehydrated and $\mathrm{Ca}^{2+}{ }_{-} \mathrm{Mt} 2 \mathrm{Alg} 8$ coiled strongly in a few seconds, but still could recover its shape quickly in a few seconds when put back into distilled water (Video S1 and S2 in the Supplementary Materials). This was in accordance with the previous research for shape responses of $\mathrm{Ca}^{2+}$-crosslinked Alg hydrogels to different organic solvents (Torres et al., 2011). It was due to the large dipole movements of acetone, which made it possible for the negatively charged dipole and positively charged dipole of the same molecule to separate (Linstrom and Mallard, 2001). Acetone was able to attack positively charged $\mathrm{Ca}^{2+}$ by its negatively charged dipole. When some $\mathrm{Ca}^{2+}$ was dissociated from the $-\mathrm{COO}-\mathrm{Ca}-\mathrm{OOC}$ - crosslinking points, the originally crosslinked Alg chains were free to coil so that more water was extracted by acetone than 
methanol (Torres et al., 2011). In this case, $\mathrm{Ca}^{2+}-\mathrm{Mt} 2 \mathrm{Alg} 8$ films shrank more and displayed a denser microstructure than those in methanol, making it possible for Mt to reorient and significantly bend. However, for $\mathrm{Ca}^{2+}-\mathrm{Mt} 3 \mathrm{Alg} 7$ and $\mathrm{Ca}^{2+}-\mathrm{Mt5} \mathrm{Alg} 5$, they did not coil in acetone as did $\mathrm{Ca}^{2+}-\mathrm{Mt} 2 \mathrm{Alg} 8$ but only slightly crumbled at the edges. This was probably due to the higher content of $\mathrm{Alg}$ in $\mathrm{Ca}^{2+}-\mathrm{Mt} 2 \mathrm{Alg} 8$ than the other two as it meant more polymer coils and thus more reshaping when the interlayer water was partially removed.

No matter whether methanol or acetone was used for treating $\mathrm{Ca}^{2+}-\mathrm{MtAlg}$ films, when they were put back in distilled water, they became soft quickly and fully recovered their original state in $4 \mathrm{~h}$, indicating shape-memory effect. In summary, the shape of $\mathrm{Ca}^{2+}-\mathrm{MtAlg}$ films was stable in either methanol or acetone except for the case of $\mathrm{Ca}^{2+}-\mathrm{Mt} 2 \mathrm{Alg} 8$ in acetone, in which it coiled strongly. All the treated films recovered their original state after being putting back in distilled water for $4 \mathrm{~h}$. Compared to $\mathrm{L}_{-} \mathrm{Ca}^{2+}-\mathrm{Mt} 3 \mathrm{Alg} 7$ and $\mathrm{Ca}^{2+}-\mathrm{Mt} 2 \mathrm{Alg} 8$ which displayed drastic shape changes in methanol or acetone (Liang et al., 2016), $\mathrm{Ca}^{2+}{ }_{-} \mathrm{Mt} 3 \mathrm{Alg} 7$ and $\mathrm{Ca}^{2+}-\mathrm{Mt} 5 \mathrm{Alg} 5$ nanocomposite hydrogel films showed significantly better shape stability. So it is likely for these two nanocomposite hydrogel films to serve in organic solvent-rich environments such as alcohol processing or organic wastewater treatment. The sensitivity of $\mathrm{Ca}^{2+}-\mathrm{Mt} 2 \mathrm{Alg} 8$ nanocomposite hydrogel film to acetone may enable it to serve as a detector of acetone.

\section{Conclusions}

Nacre-like $\mathrm{Ca}^{2+-} \mathrm{MtAlg}$ nanocomposite films were synthesised by solution casting $\mathrm{Mt} / \mathrm{Alg}$ dispersion followed by immersion in a $\mathrm{CaCl}_{2}$ solution. With the help of $\mathrm{Ca}^{2+}$ crosslinked $\mathrm{Alg}$, Mt edge-Alg electrostatic interaction, Mt-Alg hydrogen bonding, electrostatic interaction 
between $\mathrm{Ca}^{2+}$ and $\mathrm{Mt}$ layers and the aligned microstructure, $\mathrm{Ca}^{2+}-\mathrm{MtAlg}$ nanocomposite hydrogel films, even after fully swelling, could reach a high Young's modulus of $412 \mathrm{MPa}$, a high tensile strength of $28 \mathrm{MPa}$ and a high toughness of $1.81 \mathrm{MJ} \mathrm{m}^{-3}$. These results confirm that Alg chains have been successfully crosslinked by $\mathrm{Ca}^{2+}$ in the presence of the high content of $\mathrm{Mt}$ for $\mathrm{Ca}^{2+}$-MtAlg nanocomposite hydrogel films, showing layered microstructure and excellent mechanical properties even after fully swollen, which are remarkable and significantly different from the previously reported Alg nanocomposite films which were either soluble in water or extremely weak when fully swollen. The excellent mechanical properties make it possible for $\mathrm{Ca}^{2+}-\mathrm{MtAlg}$ nanocomposite hydrogel films to serve as structural materials in the aquatic environment, such as artificial membranes and medical implants.

Besides, it is proved that the optical properties of $\mathrm{Ca}^{2+}-\mathrm{MtAlg}$ nanocomposite hydrogel films differ with the different Mt/Alg ratios. All the films displayed acceptable transparency despite the high content of Mt. $\mathrm{Ca}^{2+}-\mathrm{Mt} 3 \mathrm{Alg} 7$ and $\mathrm{Ca}^{2+}-\mathrm{Mt} 5 \mathrm{Alg} 5$ also showed excellent barrier effect on ultraviolet transmittance. So $\mathrm{Ca}^{2+}{ }_{-} \mathrm{Mt} 3 \mathrm{Alg} 7$ and $\mathrm{Ca}^{2+}-\mathrm{Mt} 5 \mathrm{Alg} 5$ are highly promising in the applications of skin care or other aquatic usages such as UV-proof breeding box for raising some UV-sensitive aquatic creatures (De Mora et al., 2000). Furthermore, it is confirmed that solvent sensitivity of $\mathrm{Ca}^{2+}$-MtAlg nanocomposite hydrogel films can be significantly altered by the different $\mathrm{Mt} / \mathrm{Alg}$ ratios. When contacting with an organic solvent, only $\mathrm{Ca}^{2+}{ }_{-} \mathrm{Mt} 2 \mathrm{Alg} 8$ was very sensitive to acetone. Unlike the previously reported $\mathrm{Ca}^{2+}-\mathrm{Alg}$ systems, the others only slightly dehydrated and crumbled in either methanol or acetone, illustrating nice shape stability. All the films recovered their original shape quickly when put back in the aquatic environment, indicating excellent shape-memory property. So $\mathrm{Ca}^{2+}$ Mt3Alg7 and $\mathrm{Ca}^{2+}-\mathrm{Mt5Alg} 5$ could be also used as structural materials in the organic solventrich environment while $\mathrm{Ca}^{2+}-\mathrm{Mt} 2 \mathrm{Alg} 8$ could serve as an acetone-sensitive material. 


\section{Conflicts of interest}

There are no conflicts of interest to declare.

\section{References}

Abdollahi, M., Alboofetileh, M., Rezaei, M., Behrooz, R., 2013. Comparing physicomechanical and thermal properties of alginate nanocomposite films reinforced with organic and/or inorganic nanofillers. Food Hydrocolloids 32, 416-424.

Al-Remawi, M., 2012. Sucrose as a crosslinking modifier for the preparation of calcium alginate films via external gelation. J. Appl. Sci. 12, 727-735.

Alboofetileh, M., Rezaei, M., Hosseini, H., Abdollahi, M., 2013. Effect of montmorillonite clay and biopolymer concentration on the physical and mechanical properties of alginate nanocomposite films. J. Food Eng. 117, 26-33.

Armstrong, B.K., Kricker, A., 2001. The epidemiology of UV induced skin cancer. J. Photochem. Photobiol. 63, 8-18.

Bhattarai, N., Li, Z., Edmondson, D., Zhang, M., 2006. Alginate $\square$ based nanofibrous scaffolds: Structural, mechanical, and biological properties. Adv. Mater. 18, 1463-1467.

Bragg, W.H., Bragg, W.L., 1913. The reflection of X-rays by crystals. P. R. Soc. Lond. AConta. 88, 428-438.

Brevik, E.C., Burgess, L.C., 2012. Soils and human health. CRC Press.

Chen, B., 2004. Polymer-clay nanocomposites: an overview with emphasis on interaction mechanisms. Br. Ceram. Trans. 103, 241-249.

Chen, B., Evans, J.R., 2004. Preferential intercalation in polymer-clay nanocomposites. J. Phys. Chem. B 108, 14986-14990.

Chen, B., Evans, J.R.G., Greenwell, H.C., Boulet, P., Coveney, P.V., Bowden, A.A., Whiting, A., 2008. A critical appraisal of polymer-clay nanocomposites. Chem. Soc. Rev. 37, 568-594.

Chen, B., Evans, J.R.G., 2006. Elastic moduli of clay platelets. Scripta Mater. 54, 1581-1585.

Chen, B., Evans, J.R.G., 2006. Poly(e-caprolactone)-clay nanocomposites: structure and mechanical properties. Macromolecules. 39, 747-754.

Daemi, H., Barikani, M., 2012. Synthesis and characterization of calcium alginate nanoparticles, sodium homopolymannuronate salt and its calcium nanoparticles. Sci. Iran. 19, 2023-2028.

Das, P., Malho, J.M., Rahimi, K., Schacher, F.H., Wang, B.C., Demco, D.E., Walther, A., 2015. Nacre-mimetics with synthetic nanoclays up to ultrahigh aspect ratios. Nat. Commun. 6 .

Das, P., Thomas, H., Moeller, M., Walther, A., 2017. Large-scale, thick, self-assembled, nacre-mimetic brick-walls as fire barrier coatings on textiles. Sci. Rep. 7, 39910.

de Gruijl, F.R., van Kranen, H.J., Mullenders, L.H., 2001. UV-induced DNA damage, repair, mutations and oncogenic pathways in skin cancer. J. Photochem. Photobiol. 63, 19-27.

De Mora, S., Demers, S., Vernet, M., 2000. The effects of UV radiation in the marine environment. Cambridge University Press. 
de Moura, M.R., Guilherme, M.R., Campese, G.M., Radovanovic, E., Rubira, A.F., Muniz, E.C., 2005. Porous alginate- $\mathrm{Ca}^{2+}$ hydrogels interpenetrated with PNIPAAm networks: Interrelationship between compressive stress and pore morphology. Eur. Polym. J. 41, 28452852.

Fratzl, P., Gupta, H.S., Fischer, F.D., Kolednik, O., 2007. Hindered crack propagation in materials with periodically varying Young's modulus - Lessons from biological materials. Adv. Mater. 19, 2657-2661.

George, M., Abraham, T.E., 2006. Polyionic hydrocolloids for the intestinal delivery of protein drugs: Alginate and chitosan - a review. J. Control. Release 114, 1-14.

Giannelis, E.P., 1998. Structure and dynamics of polymer-layered silicate nanocomposites. Abstr. Pap. Am. S. 216, U321.

Gorenek, G., Akyilmaz, E., Dinckaya, E., 2004. Immobilization of catalase by entrapping in alginate beads and catalase biosensor preparation for the determination of hydrogen peroxide decomposition. Artif. Cell. Blood Sub. 32, 453-461.

Hao, W.T., Zhang, L., Wang, X.M., Wang, J., Hu, Z.H., Yang, W., 2016. Tough and strong nacre-like composites from hyperbranched poly(amido amine) and clay nanosheets crosslinked by genipin. RSC Adv. 6, 1415-1421.

Ichihashi, M., Ueda, M., Budiyanto, A., Bito, T., Oka, M., Fukunaga, M., Tsuru, K., Horikawa, T., 2003. UV-induced skin damage. Toxicology 189, 21-39.

Kevadiya, B.D., Joshi, G.V., Patel, H.A., Ingole, P.G., Mody, H.M., Bajaj, H.C., 2010. Montmorillonite-alginate nanocomposites as a drug delivery system: intercalation and in vitro release of vitamin B1 and vitamin B6. J. Biomater. Appl. 25, 161-177.

Kim, H.S., Lee, C.G., Lee, E.Y., 2011. Alginate Lyase: Structure, Property, and Application. Biotechnol. Bioprocess Eng. 16, 843-851.

Kochumalayil, J.J., Bergenstråhle-Wohlert, M., Utsel, S., Wågberg, L., Zhou, Q., Berglund, L.A., 2012. Bioinspired and highly oriented clay nanocomposites with a xyloglucan biopolymer matrix: extending the range of mechanical and barrier properties. Biomacromolecules 14, 84-91.

Kong, Q.S., Wang, B.B., Ji, Q., Xia, Y.Z., Guo, Z.X., Yu, J., 2009. Thermal degradation and flame retardancy of calcium alginate fibers. Chin. J. Polym. Sci. 27, 807-812.

Lagaly, G., Ogawa, M., Dékány, I., 2006. Clay mineral-organic interactions, in Handbook of Clay Science, Bergaya, F., Theng, B.K.G., Lagaly, G (Eds). Elsevier, Amsterdam.

Lawrie, G., Keen, I., Drew, B., Chandler-Temple, A., Rintoul, L., Fredericks, P., Grøndahl, L., 2007. Interactions between alginate and chitosan biopolymers characterized using FTIR and XPS. Biomacromolecules 8, 2533-2541.

Lee, K.Y., Mooney, D.J., 2012. Alginate: Properties and biomedical applications. Prog. Polym. Sci. 37, 106-126.

Liang, B., Zhao, H., Zhang, Q., Fan, Y., Yue, Y., Yin, P., Guo, L., 2016. Ca ${ }^{2+}$ enhanced nacre-inspired montmorillonite-alginate film with superior mechanical, transparent, fire retardancy, and shape memory properties. ACS Appl. Mater. Interfaces 8, 28816-28823.

Linstrom, P.J., Mallard, W., 2001. NIST Chemistry webbook; NIST standard reference database No. 69.

Mayer, G., 2005. Rigid biological systems as models for synthetic composites. Science 310, 1144-1147. 
Mu, J., Hou, C., Wang, H., Li, Y., Zhang, Q., Zhu, M., 2015. Origami-inspired active graphene-based paper for programmable instant self-folding walking devices. Sci. Adv. 1, e1500533.

Norajit, K., Kim, K.M., Ryu, G.H., 2010. Comparative studies on the characterization and antioxidant properties of biodegradable alginate films containing ginseng extract. J. Food Eng. 98, 377-384.

Oh, D.X., Hwang, D.S., 2013. A biomimetic chitosan composite with improved mechanical properties in wet conditions. Biotechnol. Progr. 29, 505-512.

Okada, A., Usuki, A., 2007. Twenty years of polymer-clay nanocomposites. Macromol. Mater. Eng. 292, 1449-1476.

Pawar, S.N., Edgar, K.J., 2012. Alginate derivatization: a review of chemistry, properties and applications. Biomaterials 33, 3279-3305.

Podsiadlo, P., Kaushik, A.K., Arruda, E.M., Waas, A.M., Shim, B.S., Xu, J., Nandivada, H., Pumplin, B.G., Lahann, J., Ramamoorthy, A., 2007. Ultrastrong and stiff layered polymer nanocomposites. Science 318, 80-83.

Qiu, H., Qiu, Z., Wang, J., Zhang, R., Zheng, F., 2014. Enhanced swelling and methylene blue adsorption of polyacrylamide $\square$ based superabsorbents using alginate modified montmorillonite. J. Appl. Polym. Sci. 131, 40013.

Rhim, J.W., 2011. Effect of clay contents on mechanical and water vapor barrier properties of agar-based nanocomposite films. Carbohydr. Polym. 86, 691-699.

Rhim, J.W., 2004. Physical and mechanical properties of water resistant sodium alginate films. Lebensm-Wiss. Technol. 37, 323-330.

Rytwo, G., Banin, A., Nir, S., 1996. Exchange reactions in the Ca-Mg-Na-montmorillonite system. Clays Clay Miner. 44, 276-285.

Sartori, C., Finch, D.S., Ralph, B., Gilding, K., 1997. Determination of the cation content of alginate thin films by FTIR spectroscopy. Polymer 38, 43-51.

Schaumann, K., Weide, G., 1990. Enzymatic Degradation of Alginate by Marine Fungi. Hydrobiologia 204, 589-596.

Segad, M., Jonsson, B., Akesson, T., Cabane, B., 2010. Ca/Na Montmorillonite: Structure, Forces and Swelling Properties. Langmuir 26, 5782-5790.

Soares, J., Santos, J., Chierice, G., Cavalheiro, E., 2004. Thermal behavior of alginic acid and its sodium salt. Eclet. Quim. 29, 57-64.

Su, X., Mahalingam, S., Edirisinghe, M., Chen, B., 2017. Highly stretchable and highly resilient polymer-clay nanocomposite hydrogels with low hysteresis. ACS Appl. Mater. Interfaces, 9, 22223-22234.

Su, X., Chen, B., 2018. Tough, resilient and $\mathrm{pH}$-sensitive interpenetrating polyacrylamide/alginate/montmorillonite nanocomposite hydrogels. Carbohydr. Polym. 197, 497-507.

Sun, J.Y., Zhao, X.H., Illeperuma, W.R.K., Chaudhuri, O., Oh, K.H., Mooney, D.J., Vlassak, J.J., Suo, Z.G., 2012. Highly stretchable and tough hydrogels. Nature 489, 133-136.

Tang, Z., Kotov, N.A., Magonov, S., Ozturk, B., 2003. Nanostructured artificial nacre. Nat. Mater. 2, 413-418.

Tezcan, F., Günister, E., Özen, G., Erim, F.B., 2012. Biocomposite films based on alginate and organically modified clay. Int. J. Biol. Macromol. 50, 1165-1168. 
Tonnesen, H.H., Karlsen, J., 2002. Alginate in drug delivery systems. Drug Dev. Ind. Pharm. 28, 621-630.

Torres, L.G., Velasquez, A., Brito-Arias, M.A., 2011. Ca-alginate spheres behavior in presence of some solvents and water-solvent mixtures. Adv. Microbiol. Biotechnol. 2, 8-12.

Usuki, A., Kojima, Y., Kawasumi, M., Okada, A., Fukushima, Y., Kurauchi, T., Kamigaito, O., 1993. Synthesis of nylon 6-clay hybrid. J. Mater. Res. 8, 1179-1184.

Vale, J.M., Justice, R.S., Schaefer, D.W., Mark, J.E., 2005. Calcium alginate barrier films modified by montmorillonite clay. J. Macromol. Sci. Phys. B44, 821-831.

Wan, L., Heng, P., Chan, L., 1992. Drug encapsulation in alginate microspheres by emulsification. J. Microencapsulation 9, 309-316.

Wu, D., Gao, Y., Li, W., Zheng, X., Chen, Y., Wang, Q., 2016. Selective adsorption of $\mathrm{La}^{3+}$ using a tough alginate-clay-poly(N-isopropylacrylamide) hydrogel with hierarchical pores and reversible re-deswelling/swelling cycles. ACS Sustain. Chem. Eng. 4, 6732-6743.

$\mathrm{Wu}, \mathrm{T}$., Chen, B., 2014. Biomimetic chitosan $\square$ treated clay-elastomer composites with water $\square$ responsive mechanically dynamic properties. J. Polym. Sci., Part B: Polym. Phys. 52, 55-62.

Wu, T., Farnood, R., O'Kelly, K., Chen, B., 2014. Mechanical behavior of transparent nanofibrillar cellulose-chitosan nanocomposite films in dry and wet conditions. J. Mech. Behav. Biomed. 32, 279-286.

Yang, C.H., Wang, M.X., Haider, H., Yang, J.H., Sun, J.Y., Chen, Y.M., Zhou, J.X., Suo, Z.G., 2013. Strengthening alginate/polyacrylamide hydrogels using various multivalent cations. ACS Appl. Mater. Interfaces 5, 10418-10422.

Yao, Tan, Z.H., Fang, H.Y., Yu, S.H., 2010. Artificial nacre-like bionanocomposite films from the self-assembly of chitosan-montmorillonite hybrid building blocks. Angew. Chem. Int. Edit. 49, 10127-10131.

Yao, K., Huang, S., Tang, H., Xu, Y., Buntkowsky, G., Berglund, L.A., Zhou, Q., 2017. Bioinspired interface engineering for moisture resistance in nacre-mimetic cellulose nanofibrils/clay nanocomposites. ACS Appl. Mater. Interfaces 9, 20169-20178.

Yu, C.Y., Wei, H., Zhang, Q., Zhang, X.Z., Cheng, S.X., Zhuo, R.X., 2009. Effect of ions on the aggregation behavior of natural polymer alginate. J. Phys. Chem. B 113, 14839-14843.

Zlopasa, J., Norder, B., Koenders, E.A.B., Picken, S.J., 2015. Origin of highly ordered sodium alginate/montmorillonite bionanocomposites. Macromolecules 48, 1204-1209.

Zlopasa, J., Norder, B., Koenders, E.A., Picken, S.J., 2016. Rheological investigation of specific interactions in Na Alginate and Na MMT suspension. Carbohydr. Polym. 151, 144149. 